\title{
Protective Effects and Benefits of Olive Oil and Its Extracts on Women's Health
}

\author{
Thanh Truong Giang Ly ${ }^{1,2}$, Jisoo Yun ${ }^{1,2}$, Dong-Hyung Lee ${ }^{3}$, Joo-Seop Chung ${ }^{4, *}$ and Sang-Mo Kwon ${ }^{1,2, *}$ \\ 1 Laboratory for Vascular Medicine and Stem Cell Biology, Department of Physiology, \\ Medical Research Institute, School of Medicine, Pusan National University, Yangsan 50612, Korea; \\ lythanhtruonggiang@gmail.com (T.T.G.L.); jsyun14@hanmail.net (J.Y.) \\ 2 Convergence Stem Cell Research Center, Pusan National University, Yangsan 50612, Korea \\ 3 Department of Obstetrics and Gynecology, Pusan National University Yangsan Hospital, \\ Yangsan 50612, Korea; ldh0707@hanmail.net \\ 4 Department of Hematology-Oncology, Medical Research Institute, Pusan National University Hospital, \\ Busan 49241, Korea \\ * Correspondence: hemon@pusan.ac.kr (J.-S.C.); smkwon323@pusan.ac.kr (S.-M.K.)
}

Citation: Ly, T.T.G.; Yun, J.; Lee, D.-H.; Chung, J.-S.; Kwon, S.-M. Protective Effects and Benefits of Olive Oil and Its Extracts on Women's Health. Nutrients 2021, 13, 4279. https://doi.org/10.3390/nu13124279

Academic Editor: María Dolores Mesa García

Received: 8 November 2021 Accepted: 26 November 2021 Published: 27 November 2021

Publisher's Note: MDPI stays neutral with regard to jurisdictional claims in published maps and institutional affiliations.

Copyright: (c) 2021 by the authors. Licensee MDPI, Basel, Switzerland. This article is an open access article distributed under the terms and conditions of the Creative Commons Attribution (CC BY) license (https:// creativecommons.org/licenses/by/ $4.0 /)$.

\begin{abstract}
Women and men share similar diseases; however, women have unique issues, including gynecologic diseases and diseases related to menstruation, menopause, and post menopause. In recent decades, scientists paid more attention to natural products and their derivatives because of their good tolerability and effectiveness in disease prevention and treatment. Olive oil is an essential component in the Mediterranean diet, a diet well known for its protective impact on human wellbeing. Investigation of the active components in olive oil, such as oleuropein and hydroxytyrosol, showed positive effects in various diseases. Their effects have been clarified in many suggested mechanisms and have shown promising results in animal and human studies, especially in breast cancer, ovarian cancer, postmenopausal osteoporosis, and other disorders. This review summarizes the current evidence of the role of olives and olive polyphenols in women's health issues and their potential implications in the treatment and prevention of health problems in women.
\end{abstract}

Keywords: olive oil; mediterranean diet; oleuropein; hydroxytyrosol; breast cancer; gynecologic cancer; osteoporosis; postmenopausal disorders

\section{Introduction}

Olea europaea, (Oleaceae) which is commonly known as olive tree, is one of the oldest species of trees in the Mediterranean region. Olive oil (OO) is extracted from olives-the fruits of the olive tree. The crucial role of $\mathrm{OO}$ was investigated in the 7 th century BC. Some ancient scientists have recommended using $\mathrm{OO}$ in several diseases related to the stomach and skin [1]. While Mediterranean countries produce about $70 \%$ of the $\mathrm{OO}$ in the world, Australia and USA also produce significant amounts of OO. However, the variety and quality of OO differ among these countries [2].

One of the most prominent parts of the Mediterranean diet (MD) is OO consumption, which is the principal source of fats. Other components of the MD include frequent consumption of various vegetables and fruits, cereals, fish and seafood, moderate alcohol intake, and relatively low meat intake. Current data on MD suggest that $\mathrm{OO}$ and its components have shown preventive effects in cancer [3,4], cardiovascular diseases [3,4], diabetes [3,4], and other diseases [4,5]. Monounsaturated fatty acid (oleic acid) and polyphenol constituents (such as oleuropein, hydroxytyrosol, and tyrosol) were important components that explain the protective role of $\mathrm{OO}$ in these diseases [6-8]. Among the phenolic components of OO, oleuropein (OLP) is considered the most effective biomolecule $[9,10]$.

Even though there is similarity in diseases among men and women, women have specific issues related to reproductive characteristics, including menstruation, menopause, 
and post menopause, with a large range of disorders that manifest during this period, as well as gynecological diseases. This review focusses on these women-specific conditions.

Disease prevention and potential treatment therapy research are critical requirements in medical science. In the recent decades, scientists have paid more attention to natural products and their derivatives in order to investigate their effects on disease prevention and treatment. $\mathrm{OO}$ and its active components are potential agents with promising research results. Almost all human clinical trials have evaluated the beneficial effects of $\mathrm{OO}$ in the context of MD. Therefore, the role of OO requires further investigation.

Therefore, herein, we collected current data from cellular, animal, and human studies regarding the role of MD and $\mathrm{OO}$ and its components in various aspects of women's health. The studies that were used in this review included in vitro studies, in vivo studies, meta-analyses, randomized controlled trials, and clinical trials. Therefore, this review suggests possible future research directions in this area.

\section{Structure and Bioactivity}

\subsection{OO Subtypes}

As described by the International Olive Council (IOC), virgin olive oils are the oils obtained from the fruit of the olive tree (Olea europaea L.) solely by mechanical or other physical means under conditions, particularly thermal conditions, that do not lead to alterations in the oil, and which have not undergone any treatment other than washing, decantation, centrifugation, and filtration. In addition, sensorial and chemical properties determine the classification: Extra virgin olive oil (EVOO) is a virgin olive oil which has a free acidity, expressed as oleic acid, of not more than $0.8 \mathrm{~g}$ per $100 \mathrm{~g}$, and the other characteristics of which correspond to those fixed for this category in the IOC standard. Virgin olive oil (VOO) which has a free acidity, expressed as oleic acid, of not more than $2 \mathrm{~g}$ per $100 \mathrm{~g}$ and the other characteristics of which correspond to those fixed for this category in the IOC standard. Refined olive oil is the olive oil obtained from virgin olive oils by refining methods that do not lead to alterations in the initial glycerides' structure. It has a free acidity, expressed as oleic acid, of not more than $0.3 \mathrm{~g}$ per $100 \mathrm{~g}$ and its other characteristics correspond to those fixed for this category in the IOC standard. When we talk about Olive oil in general (OO) we considered that is the oil consisting of a blend of refined olive oil and virgin olive oils fit for consumption as they are. It has a free acidity, expressed as oleic acid, of not more than $1 \mathrm{~g}$ per $100 \mathrm{~g}$ and its other characteristics correspond to those fixed for this category in the IOC standard [11]. EVOO has the best organoleptic characteristics [4]. EVOO and OO had nearly the same fatty acid component but very different phenolic content [12]. EVOO contains the highest concentration of polyphenols [13]. EVOO has a flying flavor and light color due to fatty acid removal [14]. Many factors that influenced the quality of $\mathrm{OO}$ include pre-harvest factors (the cultivar, growing area, environmental condition, soil, tree age, treatment, irrigation, fruit ripening, harvest time, fruit picking) and post-harvest factors (fruit storage, leaves removing and washing, fruit crushing, paste malaxation, oil extraction systems, oil storage, cooking) [15]. OO constituents can be divided into the saponifiable fraction (98.5-99.5\%) and the unsaponifiable fraction (0.5-1.5\%) [4]. Triglycerides are the most important part of the saponifiable fraction. Unsaponifiable fraction contains hydrocarbons, chlorophylls, tocopherols, aliphatic alcohols, sterols, phenolic compounds, volatile compounds [4]. Oleic acid is the major monounsaturated fatty acid in OO, accounting for approximately 83\% [16]. In EVOO, the mean concentration of total phenolic content was $483 \mathrm{mg} \cdot \mathrm{kg}^{-1}$ measured by $\mathrm{qNMR}$, although the phenolic content registered a large variation among the various cultivars [17]. Triacylglycerol content depends on the cultivar and the ripening stage [18]. Microclimatic, agronomic, oil's extraction conditions, the cultivar, and the harvest date influenced the sterols [19], fatty alcohols [20,21], and waxes [22,23]. Phenolic and fatty acid composition is influenced by harvest date [24] and growth environment [25].

OO polyphenols include tyrosol (4-hydroxyphenylethanol), hydroxytyrosol (3,4dihydroxyphenylethanol), oleuropein, caffeic acid, vanillic acid, syringic acid, p-coumaric 
acid, o-coumaric acid, protocatechuic acid, 4-hydroxybenzoic acid, 4-hydroxyphenylacetic acid and 3,4-dihydroxyphenylacetic acid [26]. The chemical structure of representative phenols was illustrated in Figure 1. Oleocanthal [27], tyrosol, HT [28], and OLP [29] have a wide variety of beneficial health effects [30].<smiles>C/C=C1\[C@H](CC(=O)OCCc2ccc(O)c(O)c2)C(C(=O)OC)=CO[C@@H]1O[C@@H]1O[C@H](CO)[C@@H](O)[C@H](O)[C@H]1O</smiles>

(a)<smiles>OCCc1ccc(O)c(O)c1</smiles>

(b)

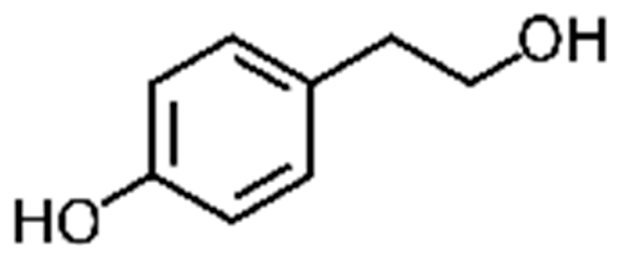

(c)

Figure 1. Chemical structure of (a) oleuropein, (b) hydroxytyrosol, and (c) tyrosol.

\subsection{Bioactivities}

OO extracts have shown protective effects against several diseases, such as hypertension, diabetes, sepsis, obesity, osteoporosis, neurodegeneration, and chronic kidney diseases [31-33]. OO consumption decreases the risk of all-cause mortality [34]. OO and its active derivatives showed antioxidant and anti-inflammatory effects [35]. Moreover, OO has antibacterial properties [36].

MD is associated with a risk reduction in the incidence and mortality of many types of cancers [37-39]. Trichopoulou et al. crudely calculated that in the group eating a traditional healthy MD diet, there was a $25 \%$ lower incidence of colorectal cancer, $15 \%$ lower incidence of breast cancer, and $10 \%$ lower incidence of prostate, pancreas, and endometrial cancer compared to the Western diet group [38]. MD can reduce the inflammatory process that contributes to cancer pathogenesis [40,41]. MD maintains the gut microbiota balance, which reduces inflammation in the intestinal mucosa, resulting in cancer reduction [42,43]. Polyphenols also show anti-cancer effects through various mechanisms related to apoptosis, proliferation, inflammation, angiogenesis, and cell cycle arrest [44]. HT showed a protective effect in the aging process via AMP-activated protein kinase (AMPK) and autophagy [33]. OO consumption decreased the risk of stomach cancer, ovarian cancer, colon cancer, endometrium cancer, particularly breast cancer. These beneficial findings have been reported in several meta-analysis studies [45-47]. OO, most likely oleic acid, regulates the HER2 gene associated with cancer [48]. Bioactivities of $\mathrm{OO}$ were characterized by a high level of monounsaturated fatty acid and antioxidant effects of polyphenols. Although various studies showed the protective effects of $\mathrm{OO}$ in the prevalence of several types of cancers. However, the mechanism by which the effects of $\mathrm{OO}$ reduce the risk of cancer remains poorly understood. So, it requires more studies that focus on the mechanism of how $\mathrm{OO}$ and its bioactive components impact the development of cancer, such as the regulation of the expression of the oncogenes. 


\section{Cancer in Women}

Cancer remains a major cause of death in humans. In 2020, the cancer statistics calculated by Ferlay et al. included 19.3 million new cases and almost 10 million cancerrelated deaths. Breast cancer is the most common cancer worldwide, with 2.26 million cases [49]. Cancer negatively affects various aspects of life, such as the economy and society as well as health and wellbeing. Although there have been therapeutic advances, including the development of targeted therapies, cancer patients still face short-term and long-term side effects from current therapies and medication resistance. More studies are required to investigate potential low-risk therapies for cancer prevention and treatment to improve the outcome and quality of life of cancer patients. Natural products have recently attracted attention for their anticancer role as potential adjunctive therapies due to their effects and because they are well tolerated. OO extracts and their bioactive components are some of the agents that have been investigated.

\subsection{Ovarian Cancer}

Ovarian cancer is one of the most common gynecologic cancers in both developed and developing countries, negatively affecting women's health and fertility. Primary epithelial ovarian cancer is the most common type of ovarian cancer. Risk factors for ovarian cancer include increasing age, infertility, and endometriosis. Approximately $20 \%$ of ovarian cancer cases have familial factors. Ovarian malignancy is diagnosed at an average age of 63. Major therapies for ovarian cancer include surgery and chemotherapy. Ovarian cancer patients with advanced stage disease face a high risk of relapse and poor outcomes [50,51].

In 2021, Benot-Dominguez et al. reported that olive leaf extract (OLE) reduces the cell proliferation cell cycle and increases apoptosis via mitochondrial impairment, which leads to a decrease in tumor growth [52]. Shabani suggested that OLP induces apoptosis, inhibits cell proliferation, and decreases cisplatin resistance by regulating miRNA expression [53]. Although older radiation therapy is rarely used in ovarian cancer, the improved radiotherapy techniques showed potential effects in ovarian cancer treatment [54]. OLP increases the sensitivity to radiotherapy in ovarian cancer patients [55]. Polyomavirus enhancer activator 3 (PEA3) a transcription factor of ETS family [56], PEA3 contributed to the organs forming include kidney [57], mammary gland [58], and limb buds [59]. PEA3 inhibits tumor formation that depends on HER-2/neu [60,61]. Menendez et al. suggested a protective mechanism of oleic acid in cancer via inhibition of the HER-2/neu gene promoter, which depends on PEA3 [62]. Tzonou et al. showed that there was a statistically significant inverse association between mono-unsaturated fat (mostly $\mathrm{OO}$ ) consumption and ovarian cancer in a case-control study in Greece [63]. Bosetti et al. reported similar results [39,64]. However, a review of meta-analyses of observational studies and randomized trials showed that the association between ovarian cancer and the MD remains elusive [32].

\subsection{Breast Cancer}

Breast cancer is the leading cause of cancer-related deaths in women. Genetic factors contribute to the risk of breast cancer [65]. Currently, breast cancer treatment therapies include surgery, radiation, endocrine therapy, neoadjuvant chemotherapy, and biological therapy. The five-year survival rate of breast cancer in women is approximately $90 \%$ in the United States [66]. The choice of treatment therapies depends on the types of breast cancer, including triple-negative breast cancer, HER2 (human epidermal growth factor receptor 2)-negative cancer, and hormone receptor (HR)-positive breast cancer, and HER1-positive diseases [67]. The application of adjuvant systemic therapy reduces mortality in breast cancer [68-70].

The anticancer role of $\mathrm{OO}$ extracts and their bioactive components in breast cancer has been evaluated in numerous in vitro, in vivo, and several clinical trials [71-75].

The OO extract contains several types of compounds. OLP has been shown to play the most important role in breast cancer cell toxicity [76,77]. In breast cancer, OLP inhibits cell proliferation, induces apoptosis, and induces cell cycle arrest [78-82]. Several 
mechanisms have been suggested, including miRNA dysregulation [79]. According to Bent-Dominguez, OLE, whose main compound is OLP, was found to increase reactive oxygen species (ROS) generation results in cell cycle delay, apoptosis, and mitochondria dysfunction [52]. Another study showed that phenolic extracts induced cell death and increased ROS production [80]. Hassan supported that OLP-induced apoptosis due to p53 pathway activation is regulated by the $B A X$ and $B C L 2$ genes [83]. Biosynthesized OLP aglycone (OLA) inhibited tamoxifen-resistant MCF-7 cell growth, whereas normal breast epithelial cells did not change. OLA also inhibits the cell cycle and induces apoptosis [84]. Messeha et al. showed that OLP altered the mRNA expression related to the apoptosis process of two kinds of triple-negative breast cancer cell lines, MDA-MB-468 and MDA-MB231, and supported that OLP is more effective in MDA-MB-468 than in MDA-MB-231 [82]. The effect of OLP was higher in MDA-MB-231 cells than in MCF-7 cells. OLP reduces breast cancer cell growth by regulating the cell cycle by decreasing NF- $\mathrm{kB}$ and cyclin D1 expression and increasing p21 expression [85]. Epithelial-mesenchymal transition (EMT) is a fundamental step in the metastasis process [86,87]. In 2019, Choupani et al. showed that OLP inhibits EMT via downregulation of sirtuin1 leads to inhibition of breast cancer cells migration [88]. In addition, combination therapy with doxorubicin and OLP may be possible due to their synergistic effect on apoptosis of human breast cancer cells [88].

HT, the main phenolic compound of the olive oil, has also been shown to be effective in breast cancer. It inhibits cell growth and cell cycle arrest by reducing the expression of cyclinD1 by upregulating c-Jun and reducing pin-1 expression [89]. Moreover, OLP and HT decrease the migration and invasion of estrogen-positive breast cancer cell lines such as MCF7 [81,90] and T47D via autophagy activation [90] or histone deacetylase regulation [81,91]. Sirianni et al. showed that OLE and HT inhibit the ERK1/2 activation that is dependent on E2 [92].

Another bioactive phenolic compound from EVOO purification is S-(-) oleocanthal (OC). OC inhibited triple-negative breast cancer progression and metastasis to the lung in two heterogeneous triple-negative breast cancer animal models, and no considerable toxicity was observed. Additionally, using a microarray gene signature, this study showed that OC treatment protects almost all steps of cancer progression, including cell-to-cell adhesion signaling, interaction, invasion, and migration [93].

$\mathrm{OO}$ and its active components demonstrated effects in cancer formation, progression, metastasis, prognosis, and response to treatment therapy. MCF-7 breast cancer cell line proliferation requires the protein tyrosine phosphatase 1B (PTP1B) [94], an enzyme that plays a crucial anti-cancer role [95]. OLP reduces PTP1B activity, which is correlated with cell growth and cell cycle delay. This suggests that PTP1B phosphatase may be a target for OLP treatment in breast cancer [96]. HER-2 plays an important role in various aspects of cancer progression in breast cancer, including its etiology, progression, and response to therapies. Over-expression of HER2 leads to poor prognosis, decreased relapse time, and low survival [97-99]. This study showed that EVOO inhibits HER2 activity by increasing the proteasomal degradation of this protein [100]. Menendez et al. showed that EVOO polyphenols also inhibit fatty acid synthase (FASN) expression in HER-2-overexpression breast cancer [101]. FASN is strongly expressed in many human cancers and is positively correlated with poor prognosis and low survival; therefore, it is considered an oncoprotein [102]. This study also examined the role of EVOO, especially the role of OLP aglycone in the improvement of the effect and resistance of trastuzumab in vitro [77]. Therefore, OO may be synergistic with the current therapies. OLP also showed anti-metastatic effects by decreasing matrix metalloproteinase (MMP) expression and increasing the expression of tissue inhibitors of metalloproteinases [103]. HDCA plays an important role in cell proliferation and apoptosis [104,105]. OLP decreases HDCA expression, including HDAC2, HDAC3, and HDAC4 [81,91]. Plasminogen activator inhibitor-1 (PA-1) contributes to blood clotting, and increased PA-1 expression is associated with poor outcomes in breast cancer $[106,107]$. Tzekaki et al. supported OLP as a strong binder to PA-1. EVOO and OLP 
treatment inhibited PA-1 expression in ER-/PR- breast cancer cell lines. Moreover, this study showed that EVOO and OLP suppressed cell growth and caspase activation [108].

Cancer stem cells (CSC), characterized by self-renewal and differentiation, contribute to the pathogenesis of therapy resistance, tumor formation, and metastasis abilities [109-111]. Therefore, CSC are considered a target for investigating novel therapies. Corominas-Faja et al. showed EVOO-derived crude phenolic extract (EVOO-PE) inhibited CSC formation in the first step. Because of the most abundant compound in EVOO-PE, purified OLA and decarboxymethylated oleuropein aglycone (DOLA) were used for further experiments. They observed DOLA has greater inhibitory effects compared to OLA. DOLA significantly decreased the mammosphere-forming in four traditional breast cancer cell lines (DCIS.com, T47D, ZR-75-1, and SUM-159). For in vivo tumor formation ability, they used SM-159 cells pre-treated DOLA $20 \mu \mathrm{g} / \mathrm{L}$ for 3 days with daily re-feeding and injected subcutaneously. DOLA reduced tumor formation compared to the control group. DOLA also suppressed the growth of tumors in the orthotopic implantation model. DOLA also regulated the gene expression related to stem cell fate. In silico computational studies determined DOLA as a dual mTOR/DNMT inhibitor [112].

In summary, underlying molecular mechanisms of OO function, especially OLP, it has been suggested that diverse signaling pathways related to apoptosis, cell growth, cell cycle, and ROS generation contribute to tumor growth and metastasis. In addition, it regulates many genes related to the prognosis and outcomes of breast cancer patients.

Regarding OO, MD, and its constituents in clinical trials, long-term MD+EVOO reduced breast cancer incidence in a study $(n=4152)$ performed from 2003 to 2009 [74]. In 1208 patients with early stage breast cancer, a MD combined with exercise decreased breast cancer recurrence [75]. Skouroliakou et al. evaluated the MD intervention in postmenopause breast cancer survivors for 6 months. There was a significant decrease in body weight, body fat mass, waist circumference, body mass index, and increase in the vitamin C, CoQ10 levels in the intervention group. In the comparison between the two groups at the end of the study, registered blood glucose concentration was significantly lower while the vitamin C, CoQ10 levels were considerably higher compared to the control group [113].

In 2018, in a clinical trial using HT in combination with omega-3 fatty acid and curcumin, Martinez et al. found reduced levels of C-reactive protein, a marker of inflammation and pain in early stage breast cancer patients treated with hormonal therapy [114].

OO intake can reduce breast cancer risk [45-47,115]. In 2021, a meta-analysis that assessed the $\mathrm{OO}$ consumption and breast cancer risk data from 10 observational studies (two prospective studies and 8 case-control studies) showed that $\mathrm{OO}$ intake may decrease breast cancer risk, the random effects summary OR for breast cancer was $0.48(95 \% \mathrm{CI}=0.09-2.70)$ for prospective studies and $0.76(95 \% \mathrm{CI}=0.54-1.06)$ in case-control studies, comparing women with the highest intake to those with the lowest intake category of olive oil. The relationship between breast cancer risk and dose-response olive oil was not significant; the OR $(95 \% \mathrm{CI})$ for breast cancer in the dose-response meta-analysis with a $14 \mathrm{~g} /$ day increase in olive oil intake was $0.93(0.83-1.04)$ [116].

\subsection{Cervical Cancer}

Cervical cancer is the fourth most common cancer in women and is one of the leading causes of death in developing countries [117]. In 2020, 604,000 new cases of cervical cancer and 342,000 deaths were reported worldwide [118]. Human papillomavirus (HPV) infection accounts for $99.7 \%$ of cervical cancers [119]. Treatment of cervical cancer includes surgery, chemotherapy, and radiation, which vary with disease stage.

Torics et al. (2020) assessed the effect of the phenolic compounds in EVOO on cervical cancer. They showed that EVOO phenolic extracts inhibit cell growth, although in combination with current cancer therapy such as irinotecan and 5-fluorouracil, the results were not statistical different [120]. OO polyphenols increased GSH levels, the most crucial intracellular antioxidant molecules measured by flow cytometry, but did not alter ROS lev- 
els. HT may have a higher antioxidant effect than tyrosol [121]. A cross-sectional study in Italy by Barchitta et al. suggested that MD might lower the risk of HPV infection and highgrade cervical intraepithelial neoplasia [122]. OLP increases apoptosis by upregulating the JNK/SPAK signaling pathway [123].

Another study showed that a high olive diet enhanced cervical cancer growth and metastasis in a mouse xenograft model. Oleic acid increases cell proliferation, migration, and invasion. Oleic acid induces CD36 via SRC/ERK activation, which contributes to cervical cancer formation and the progression of cervical cancer [124]. Zhang et al. reported that a high olive diet can enhance tumor growth in cervical cancer in vivo. Oleic acid increased the proliferation and migration of cervical cancer cells. This study also showed the different gene expression patterns altered by the olive oil diet and a set of hub genes for further investigation [125].

\subsection{Endometrial Cancer}

Endometrial cancer is one of the most common cancers in women. Estrogen is a major risk factor, obesity, low physical activity, and poor nutrition are also other risk factors for endometrial cancer. The major histopathological features of endometrial cancer originate from the epithelium. Its incidence peaks between the ages of 60 and 70 years. Treatment methods include surgery and adjuvant chemotherapy for high-risk endometrial cancer [126-128]. The study evaluating the role of $\mathrm{OO}$ and its extracts in endometrial cancer is not available.

\subsection{Vaginal Cancer}

The incidence of vaginal cancer is lower than that of ovarian and cervical cancers. Most vaginal tumors are squamous carcinomas, and other histologic types are less common. The majority of vaginal cancers are a result of metastasis from other organs such as the endometrium, cervix, vulva, ovary, breast, rectum, and kidney. The mean age of the patients tends to be around 60 years. Treatment therapy decisions depend on many factors, including the location, size, and clinical stage of the tumor, and these are also prognostic factors for vaginal cancer patients. Treatment therapies include surgery, radiation, and chemotherapy $[66,126,129,130]$. The evidence related to the association between OO, active phenolic constituents, and vaginal cancer is not available.

\subsection{Vulvar Cancer}

Primary vulvar cancer is a rare disease that is less common than vaginal cancer. The major histopathology is squamous cell carcinoma. Treatment therapy consists of surgery, radiation, and chemotherapy. HPV infection is a major type of vulvar cancer [131-133]. The effect or impact of MD or OO and its components in vulvar cancer is not available. A study assessed the risk of fat consumption in mice in relation to reproductive system tumor formation. They used four groups of fat, including corn oil, fish oil, OO, and lard. There were no significant differences among these groups [134].

\section{Postmenopausal Disorders}

Postmenopausal women suffer from several disorders due to the reduction in estrogen and other hormones, including emotional fluctuations, hot flashes, depression, anxiety, and vaginal dryness from perimenopause to post menopause [135]. The incidence of obesity, metabolic syndrome, cardiovascular diseases, and osteoporosis is associated with menopause [136]. In ovariectomized rats, EVOO reduced IL-6, malonyldialdehyde, and nitrate levels. Thus, $\mathrm{OO}$ has antioxidant and anti-inflammatory effects during menopause. This study also evaluated cancer markers, including carbohydrate antigen 125 (CA125), carcinoembryonic antigen (CEA), $\alpha$-fetoprotein (AFP), and carbohydrate antigen 19-9 (CA19-9), in two groups of gynecologic cancer patients who had bilateral ovarian and bilateral fallopian excisions and were consuming either 0 or $50 \mathrm{~mL}$ of OO every morning. This study showed a significant decrease in the concentrations of CA125, CEA, and AFP in 
the $\mathrm{OO}$ consumption group [137]. OO in combination with vitamin D3, K1, and $\mathrm{B} 6$ also showed beneficial effects on platelet function and nitrosative stress prevention in healthy postmenopausal women [138]. Salvini et al. reported that high EVOO consumption, especially HT, prevented oxidative DNA damage in postmenopausal women [139]. Because of the limited number of patients, further studies are required.

Although the evidence is relatively limited, $\mathrm{OO}$ and its components have a positive impact on other aspects of women's health, such as menstruation and sex. This study showed a similar effect of EVOO and ibuprofen in relieving the symptoms of primary dysmenorrhea, including pain scores and pain durations [140]. Sexual disorders are a common disorder in breast cancer survivors. Juraskova et al. showed that OO, during intercourse is one of the factors of OVERcome therapy, and like OO, vaginal exercise, and moisturizer, improved dyspareunia and sexual disorders in breast cancer patients [141].

\section{Osteoporosis}

Osteoporosis is a common chronic disease that affects most elderly persons, with women accounting for two-thirds of cases. The risk of osteoporosis increases dramatically in the postmenopausal period. Osteoporosis is a complication that leads to an increase in mortality in patients with osteoporosis [142]. Olive and olive polyphenols have been shown to increase bone mineral density and protect bone health [143]. Liu et al. reported that EVOO increased bone mineral density (BMD) in rats in an artificial menopause state due to ovariectomy [137]. Hagiwara et al. also reported the suppression of bone loss in ovariectomized mice when they used OLP and HT orally at 3-day intervals [144]. Puel et al. in several studies showed the effect of $\mathrm{OO}$ and its components in bone loss prevention in animal models [145-148]. Saleh et al. also showed similar results in osteoporosis models in rats [149]. Several studies have suggested that olive polyphenols protect bone health via oxidative stress reduction and anti-inflammatory effects. Olive polyphenols enhance the growth and differentiation of pre-osteoblasts and decrease osteoclast formation $[143,144,150,151]$. Gamma-linolenic acid originating from OO inhibits bone resorption and increases calcium levels in bone [152]. Filip et al. showed that polyphenol extract from $\mathrm{OO}$ increases osteocalcin concentration, a bone formation marker, and may help maintain lumbar BMD [153]. In contrast, Keiler et al. showed that using the total polyphenolic fraction of EVOO did not attenuate bone loss due to ovariectomy in rat models [154].

\section{Cardiovascular Diseases and Type 2 Diabetes}

OO positively impacts cardiovascular diseases. The available data demonstrated its protective role on vascular endothelial functions, lowering triglyceride levels, LDLcholesterol reduction, pro-thrombotic reduction, and anti-atherogenic effects [155-160]. EVOO also improved dyslipidemia in postmenopausal women [161]. Jimenez-Morales showed that EVOO interacted with the NOS3 Glu298Asp polymorphism to reduce endothelial dysfunction in patients with metabolic syndrome [160]. The protective effect of $\mathrm{OO}$ was observed in a meta-analysis, and $\mathrm{OO}$ consumption can reduce the risk of coronary heart disease and stroke [162]. OO also has anti-inflammatory and antioxidant effects [163,164]. The beneficial effects of $\mathrm{OO}$ were observed in young women with mild hypertension. Additionally, OO enhanced endothelial function in this group [165]. Moreover, OO showed beneficial effects on anti-inflammatory markers related to cardiovascular diseases, such as C-reactive protein and interleukin-6 [166]. Lockyer et al. supported that OLE protects vascular function and that OLE also significantly decreases the concentration of the cytokine IL-8. This study used a digital volume pulse to measure vascular function in a randomized, double-blind, placebo-controlled, crossover, acute intervention trial in humans [167]. Filip et al. documented that polyphenol extract $\left(\right.$ Bonolive $^{\circledR}$ ) from olives decreased the total and LDL-cholesterol levels in postmenopausal women [153].

OO consumption also reduced the risk of type 2 diabetes in a meta-analysis study [168]. OLP also showed a potential effect in preventing hypoglycemia and oxidative stress-related 
complications in diabetic rabbits via a positive impact on enzymatic and non-enzymatic antioxidants [164].

\section{Conclusions and Future Directions}

The collected evidence showed the beneficial effects of $\mathrm{OO}$ on women's health, especially in breast cancer, ovarian cancer, postmenopausal osteoporosis, cardiovascular disease, type 2 diabetes, and other disorders, along with the potential action mechanisms. Two groups of $\mathrm{OO}$ constituents were investigated: monounsaturated fatty acids (oleic acid) and the phenolic components. However, the bioactivities of the two groups might have contrasting effects, for instance, in cervical cancer. Almost all human studies have evaluated the effect of $\mathrm{OO}$ in the context of MD, so interpreting these studies might be challenging. However, evidence for gynecologic malignancy is limited, and the results remain inconsistent. Therefore, further studies are required to clarify the role of $\mathrm{OO}$ in this disease group, especially the active components, and to investigate the underlying mechanisms. The roles of $\mathrm{OO}$ in various aspects of women's health are summarized in Table 1. 
Table 1. The role of OO in various aspects of women's health

\begin{tabular}{|c|c|c|c|c|}
\hline Diseases & Products & Author & Study Design & Results \\
\hline \multirow[t]{7}{*}{ Osteoporosis } & OOE & Casado-Diaz et al. 2017 [169] & $\begin{array}{l}\text { Human mesenchymal stem cell and } \\
\text { serum from postmenopausal women }\end{array}$ & Increased osteoblastogenesis \\
\hline & $\begin{array}{l}\text { Polyphenol extract from OO } \\
\left(\text { Bonolive }^{\circledR}\right)\end{array}$ & Filip et al. 2015 [153] & $\begin{array}{l}\text { A double blind, placebo-controlled study } \\
\text { in } 64 \text { postmenopausal women }\end{array}$ & $\begin{array}{l}\text { Increased osteocalcin levels } \\
\text { Lumbar BMD maintenance } \\
\text { compared to BMD reduction in the } \\
\text { control group }\end{array}$ \\
\hline & Total phenolic extract from EVOO & Keiler et al. 2013 [154] & Ovariectomized rats & No attenuation of bone loss \\
\hline & OLP and HT & Hagiwara et al. 2011 [144] & MC3T3-E1 cell line, ovariectomized mice & $\begin{array}{l}\text { Decreased bone loss in } \\
\text { ovariectomized mice }\end{array}$ \\
\hline & $\begin{array}{l}\text { OO } \\
\text { Black lucques olives } 2007\end{array}$ & Saleh et al. 2011 [149] & Ovariectomy-induced osteoporosis rats & Decline in bone loss \\
\hline & $\begin{array}{l}\text { EVOO and OLP } 2004 \\
\text { OLP } 2006 \\
\text { HT and tyrosol } 2008\end{array}$ & $\begin{array}{l}\text { Puel et al. 2004, 2006, 2007, 2008, } \\
\text { [145-148] }\end{array}$ & Ovariectomy/inflammation model & Increase in bone mineral density \\
\hline & Gamma-linolenic acid & Claassen et al. 1995 [152] & Rats & $\begin{array}{l}\text { Inhibition of bone resorption } \\
\text { Increase in calcium level }\end{array}$ \\
\hline \multicolumn{5}{|c|}{ Postmenopausal disorders } \\
\hline & OO plus Vitamin D3, K, B6 & Vigini et al. 2017 [138] & $\begin{array}{l}\text { Human, single-center, randomized } \\
\text { placebo-controlled trial }\end{array}$ & $\begin{array}{l}\text { Reduction in nitric oxide levels } \\
\text { Maintenance of platelet function }\end{array}$ \\
\hline \multirow{6}{*}{ Ovarian cancer } & EVOO & Anderson-Vasquez et al. 2015 [161] & $\begin{array}{l}\text { A prospective, longitudinal and } \\
\text { comparative study, } 18 \text { healthy } \\
\text { postmenopausal women }\end{array}$ & Dyslipidemia improvement \\
\hline & 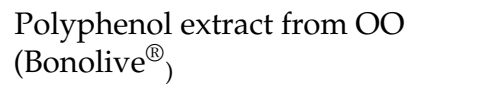 & Filip et al. 2015 [153] & \multirow{2}{*}{$\begin{array}{l}\text { A double blind, placebo-controlled study, } \\
64 \text { postmenopausal women } \\
\text { Randomized cross-over intervention trial, } \\
\text { postmenopausal women }\end{array}$} & $\begin{array}{l}\text { Decreased the total and } \\
\text { LDL-cholesterol }\end{array}$ \\
\hline & High-phenol EVOO & Salvini et al. 2006 [139] & & Prevented oxidative DNA damage \\
\hline & OLP & Sheikhshabani et al. 2021 [53] & A2780S and A2780/CP cell lines & $\begin{array}{l}\text { Increased apoptosis } \\
\text { inhibition of cell proliferation } \\
\text { Decreases in cisplatin resistance } \\
\text { Viability inhibition increased }\end{array}$ \\
\hline & OLE & Bennot-Dominguez et al. 2021 [52] & MDA-MB-231 and OVCAR-3 & $\begin{array}{l}\text { apoptosis, increased ROS } \\
\text { production, mitochondria } \\
\text { dysfunction was induced }\end{array}$ \\
\hline & OLP & Xing et al. 2017 [55] & $\begin{array}{l}\text { In vitro in the Caov3 and Skov } 3 \text { cell line } \\
\text { and in a xenograft mouse model }\end{array}$ & $\begin{array}{l}\text { Upregulated miR-299 expression } \\
\text { and inhibited HPSE1 expression }\end{array}$ \\
\hline
\end{tabular}


Table 1. Cont.

\begin{tabular}{|c|c|c|c|c|}
\hline Diseases & Products & Author & Study Design & Results \\
\hline \multirow{12}{*}{ Breast cancer } & \multirow[t]{2}{*}{ Oleic acid } & Menendez et al. [62] & SK-OV3 & $\begin{array}{l}\text { Repressed HER2-neu expression vic } \\
\text { PEA3 protein action }\end{array}$ \\
\hline & & Tzonou et al. 1993 [63] & Case-control & Risk reduction \\
\hline & $\mathrm{OO}$ & Bosetti et al. 2009 [39] & Case-control & Risk reduction \\
\hline & S-(-)-Oleocanthal (OC) & Qusa et al. 2021 [93] & $\begin{array}{l}\text { MDA-MB-231 in vivo using two kinds of } \\
\text { animal models: breast cancer } \\
\text { patient-derived xenograft model and } \\
\text { transgenic MMTV-PyVT }\end{array}$ & $\begin{array}{l}\text { Inhibited cancer progression and } \\
\text { metastasis. Investigated the } \\
\text { mechanism at the gene level. } \\
\text { Controlled the gene related to } \\
\text { progression and metastasis } \\
\text { Inhibited cell proliferation }\end{array}$ \\
\hline & OLP & Asgharzade et al. 2020 [79] & MCF-7 and MDA-MB-231 & $\begin{array}{l}\text { Increased apoptosis } \\
\text { Dysregulated miRNA }\end{array}$ \\
\hline & OLP & Messeha et al. 2020 [82] & MDA-MB-468 and MDA-MB-231 & $\begin{array}{l}\text { MDA-MB- } 468 \text { is more susceptible to } \\
\text { OLP than MDA-MB- } 231\end{array}$ \\
\hline & OLP and HT & Lu et al. 2020 [90] & MCF7 and T47D & $\begin{array}{l}\text { Decreased migration and invasion } \\
\text { via autophagy activation }\end{array}$ \\
\hline & OLA & Mazzei et al. 2020 [84] & MDA-MB-231, tamoxifen-resistant MCF-7 & \\
\hline & OLP & Reboredo-Rodríguez et al. 2018 & MCF-7 & $\begin{array}{l}\text { Induced cell death and increased } \\
\text { ROS production }\end{array}$ \\
\hline & EVOO & Corominas-Faja et al. 2018 [112] & $\begin{array}{l}\text { In vivo and in vitro HMLER, } \\
\text { MCF10DCIS.com, SUM-159, MCF-7 }\end{array}$ & $\begin{array}{l}\text { Inhibited mammosphere formation, } \\
\text { decreased tumor formation, } \\
\text { regulated the expression of stem cell } \\
\text { fates, inhibited self-renewal } \\
\text { capacities via DNMT regulation and } \\
\text { mTOR inhibition. }\end{array}$ \\
\hline & OLP & Bayat et al. 2018 [81] & MCF-7 & $\begin{array}{l}\text { Induced apoptosis, decreased } \\
\text { migration and invasion } \\
\text { Decreased HDAC2 and HDAC3 } \\
\text { expression }\end{array}$ \\
\hline & OLP & Mansouri et al. 2018 [91] & MCF-7 & $\begin{array}{l}\text { Inhibited cell growth and invasion } \\
\text { Induced apoptosis via HDAC } \\
\text { regulation }\end{array}$ \\
\hline
\end{tabular}


Table 1. Cont.

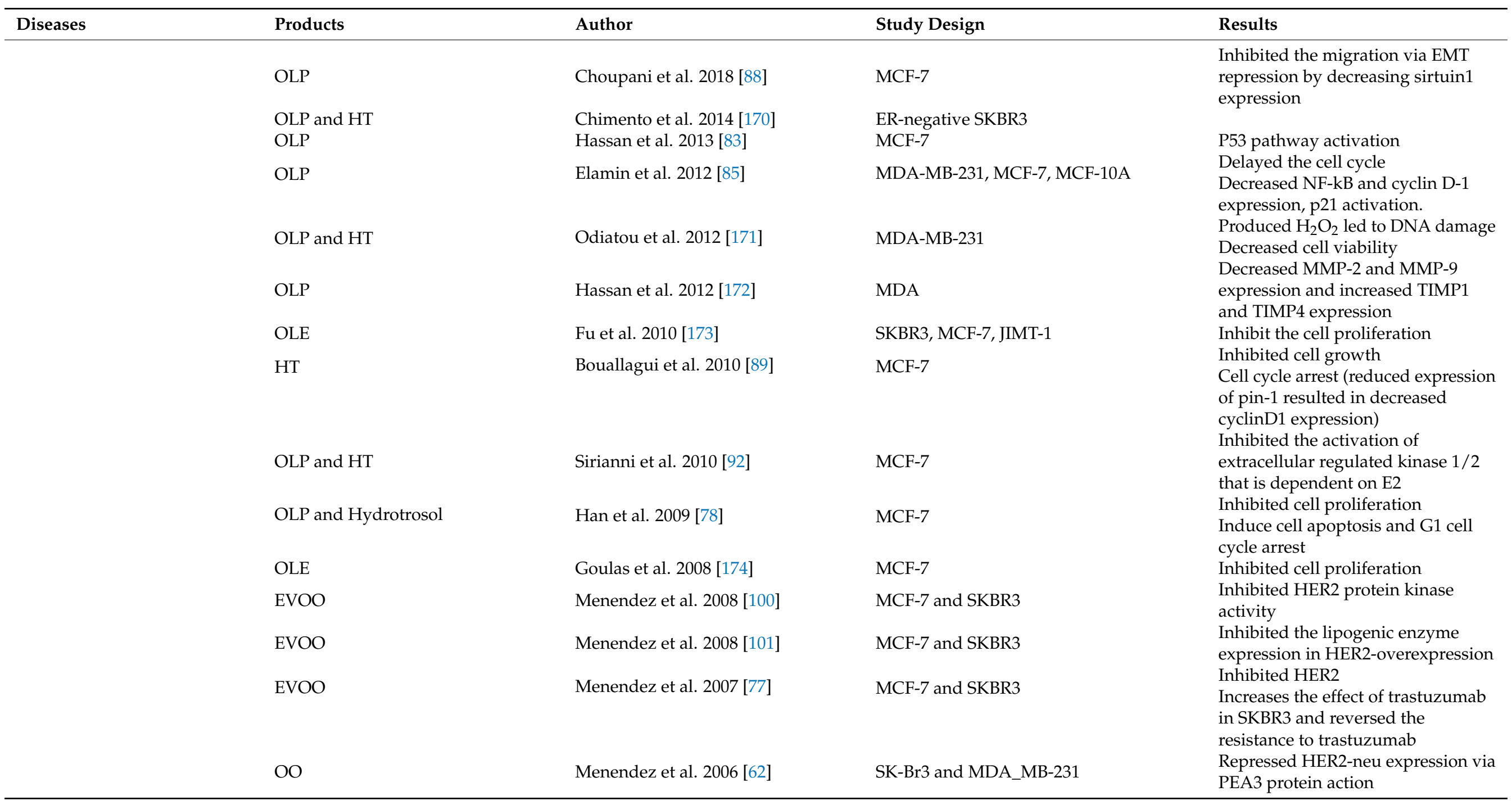


Table 1. Cont.

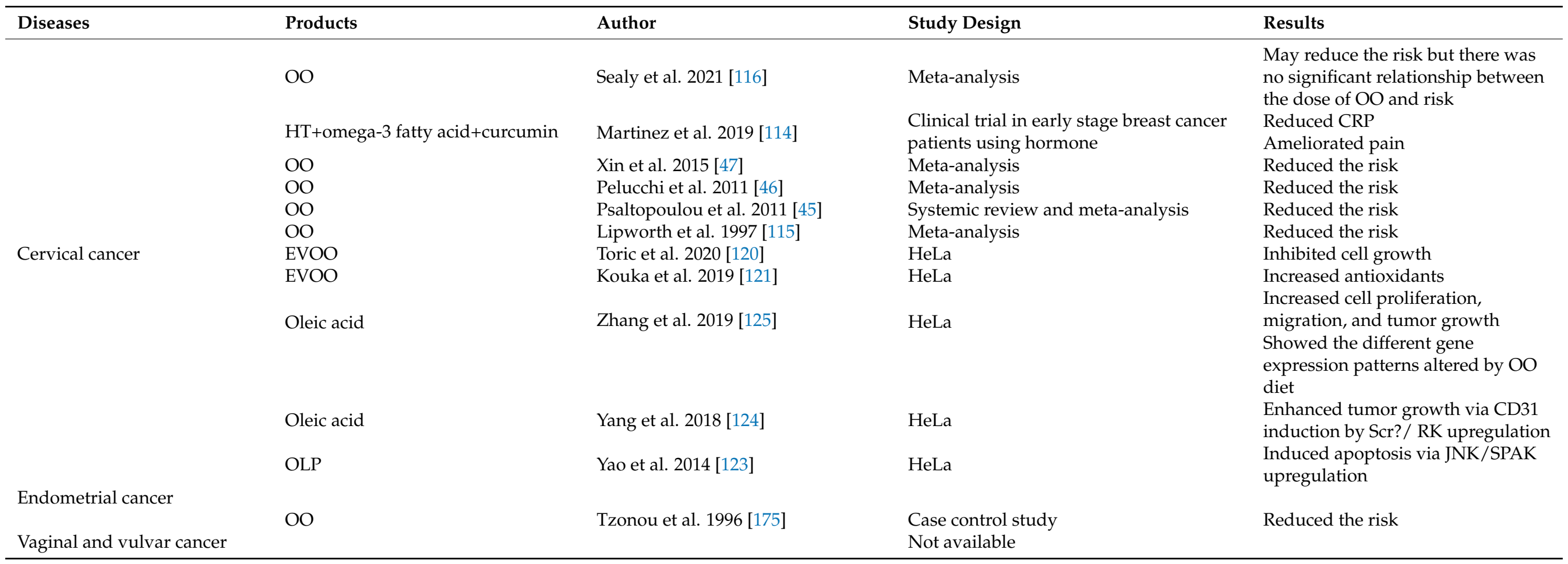


Author Contributions: T.T.G.L. conceptualized the review, performed literature survey, wrote the manuscript, and made the figure, table. S.-M.K. and J.-S.C. edited and supervised. J.Y. and D.-H.L. edited. All authors have read and agreed to the published version of the manuscript.

Funding: This work was supported by the National Research Foundation of Korea (grant nos. 2021R1I1A3055686, NRF-2020R1A2C2101297, and NRF-2015R1A5A2009656) and the Korean Health Technology R\&D Project, Ministry of Health and Welfare, Republic of Korea (grant nos. HI18C2459 and HI18C2458).

Conflicts of Interest: The authors declare no conflict of interest.

$\begin{array}{ll}\text { Abbreviations } \\ \text { PEA3 } & \text { Polyomavirus enhancer activator 3 } \\ \text { DNMT } & \text { DNA methyltransferase } \\ \text { EVOO-PE } & \text { EVOO-derived crude phenolic extract } \\ \text { CSC } & \text { cancer stem cell } \\ \text { DOLA } & \text { decarboxymethyl oleuropein aglycone } \\ \text { EMT } & \text { Epithelial-mesenchymal transition } \\ \text { IOC } & \text { International Olive Council } \\ \text { EVOO } & \text { extra virgin olive oil } \\ \text { OLE } & \text { olive leaf extract } \\ \text { OLP } & \text { oleuropein } \\ \text { OC } & \text { S-(-)-Oleocanthal } \\ \text { PA-1 } & \text { plasminogen activator inhibitor-1 } \\ \text { MT } & \text { Mediterranean } \\ \text { MD } & \text { Mediterranean diet } \\ \text { HT } & \text { hydroxytyrosol } \\ \text { OO } & \text { olive oil } \\ \text { ROS } & \text { reactive oxygen species } \\ \text { HDCA } & \text { histone deacetylase } \\ \text { MMP } & \text { matrix metalloproteinase } \\ \text { PTP1B } & \text { protein tyrosine phosphatase 1B } \\ \text { FASN } & \text { fatty acid synthetase } \\ \text { HPV } & \text { human papillomavirus } \\ \text { BMD } & \text { bone mineral density } \\ & \end{array}$

\section{References}

1. Nomikos, N.N.; Nomikos, G.N.; Kores, D.S. The use of deep friction massage with olive oil as a means of prevention and treatment of sports injuries in ancient times. Arch. Med. Sci. AMS 2010, 6, 642. [CrossRef]

2. Vossen, P. Olive oil: History, production, and characteristics of the world's classic oils. HortScience 2007, 42, 1093-1100. [CrossRef]

3. Foscolou, A.; Critselis, E.; Panagiotakos, D. Olive oil consumption and human health: A narrative review. Maturitas 2018, 118, 60-66. [CrossRef]

4. La Lastra, C.; Barranco, M.; Motilva, V.; Herrerias, J. Mediterrranean diet and health biological importance of olive oil. Curr. Pharm. Des. 2001, 7, 933-950. [CrossRef]

5. Abenavoli, L.; Milanović, M.; Milić, N.; Luzza, F.; Giuffrè, A.M. Olive oil antioxidants and non-alcoholic fatty liver disease. Expert Rev. Gastroenterol. Hepatol. 2019, 13, 739-749. [CrossRef] [PubMed]

6. Owen, R.; Haubner, R.; Würtele, G.; Hull, W.; Spiegelhalder, B.; Bartsch, H. Olives and olive oil in cancer prevention. Eur. J. Cancer Prev. 2004, 13, 319-326. [CrossRef]

7. Nocella, C.; Cammisotto, V.; Fianchini, L.; D’Amico, A.; Novo, M.; Castellani, V.; Stefanini, L.; Violi, F.; Carnevale, R. Extra virgin olive oil and cardiovascular diseases: Benefits for human health. Endocr. Metab. Immune Disord.-Drug Targets (Former. Curr. Drug Targets-Immune Endocr. Metab. Disord.) 2018, 18, 4-13. [CrossRef] [PubMed]

8. Ditano-Vázquez, P.; Torres-Peña, J.D.; Galeano-Valle, F.; Pérez-Caballero, A.I.; Demelo-Rodríguez, P.; Lopez-Miranda, J.; Katsiki, N.; Delgado-Lista, J.; Alvarez-Sala-Walther, L.A. The fluid aspect of the Mediterranean diet in the prevention and management of cardiovascular disease and diabetes: The role of polyphenol content in moderate consumption of wine and olive oil. Nutrients 2019, 11, 2833. [CrossRef]

9. Hashim, Y.Z.; Eng, M.; Gill, C.I.; McGlynn, H.; Rowland, I.R. Components of olive oil and chemoprevention of colorectal cancer. Nutr. Rev. 2005, 63, 374-386. [CrossRef] 
10. Owen, R.W.; Giacosa, A.; Hull, W.E.; Haubner, R.; Würtele, G.; Spiegelhalder, B.; Bartsch, H. Olive-oil consumption and health: The possible role of antioxidants. Lancet Oncol. 2000, 1, 107-112. [CrossRef]

11. International Olive Council Regulation. In Trade Standard Applying to Olive Oils and Olive Pomace Oils; COI/T.15/NC No 3/Rev. 12 June 2018; International Olive Council: Madrid, Spain, 2018.

12. Montedoro, G.; Servili, M.; Baldioli, M.; Miniati, E. Simple and hydrolyzable phenolic compounds in virgin olive oil. 1. Their extraction, separation, and quantitative and semiquantitative evaluation by HPLC. J. Agric. Food Chem. 1992, 40, 1571-1576. [CrossRef]

13. Kalogeropoulos, N.; Tsimidou, M.Z. Antioxidants in Greek virgin olive oils. Antioxidants 2014, 3, 387-413. [CrossRef] [PubMed]

14. Fernández, A.G.; Adams, M.R.; Fernández-Díez, M. Table Olives: Production and Processing; Springer Science \& Business Media: Berlin/Heidelberg, Germany, 1997.

15. Mele, M.A.; Islam, M.Z.; Kang, H.-M.; Giuffrè, A.M. Pre-and post-harvest factors and their impact on oil composition and quality of olive fruit. Emir. J. Food Agric. 2018, 30, 592-603.

16. Ramirez-Tortosa, M.C.; Granados, S.; Quiles, J.L. Chemical Composition, Types and Characteristics of Olive Oil; CABI Publishing: Oxford, UK, 2006.

17. Diamantakos, P.; Ioannidis, K.; Papanikolaou, C.; Tsolakou, A.; Rigakou, A.; Melliou, E.; Magiatis, P. A New Definition of the Term "High-Phenolic Olive Oil" Based on Large Scale Statistical Data of Greek Olive Oils Analyzed by qNMR. Molecules 2021, 26, 1115. [CrossRef]

18. Giuffrè, A. Variation in triacylglycerols of olive oils produced in Calabria (Southern Italy) during olive ripening. Riv. Ital. Sostanze Grasse 2014, 91, 221-240.

19. Giuffrè, A.M.; LouAdj, L. Influence of crop season and cultivar on sterol composition of monovarietal olive oils in Reggio Calabria (Italy). Czech J. Food Sci. 2013, 31, 256-263. [CrossRef]

20. Giuffrè, A. The effects of cultivar and harvest year on the fatty alcohol composition of olive oils from Southwest Calabria (Italy). Grasas Aceites 2014, 65, e011. [CrossRef]

21. Giuffrè, A.M. Evolution of fatty alcohols in olive oils produced in Calabria (Southern Italy) during fruit ripening. J. Oleo Sci. 2014, 63, 485-496. [CrossRef]

22. Giuffrè, A.M. Influence of harvest year and cultivar on wax composition of olive oils. Eur. J. Lipid Sci. Technol. 2013, 115, 549-555. [CrossRef]

23. Giuffrè, A. Wax ester variation in olive oils produced in Calabria (Southern Italy) during olive ripening. J. Am. Oil Chem. Soc. 2014, 91, 1355-1366. [CrossRef]

24. Giuffrè, A.; Piscopo, A.; Sicari, V.; Poiana, M. The effects of harvesting on phenolic compounds and fatty acids content in virgin olive oil (cv Roggianella). Riv. Ital. Sostanze Grasse 2010, 87, 14-23.

25. Di Vaio, C.; Nocerino, S.; Paduano, A.; Sacchi, R. Influence of some environmental factors on drupe maturation and olive oil composition. J. Sci. Food Agric. 2013, 93, 1134-1139. [CrossRef]

26. El Riachy, M.; Priego-Capote, F.; León, L.; Rallo, L.; Luque de Castro, M.D. Hydrophilic antioxidants of virgin olive oil. Part 1: Hydrophilic phenols: A key factor for virgin olive oil quality. Eur. J. Lipid Sci. Technol. 2011, 113, 678-691. [CrossRef]

27. Parkinson, L.; Keast, R. Oleocanthal, a phenolic derived from virgin olive oil: A review of the beneficial effects on inflammatory disease. Int. J. Mol. Sci. 2014, 15, 12323-12334. [CrossRef]

28. Hu, T.; He, X.-W.; Jiang, J.-G.; Xu, X.-L. Hydroxytyrosol and its potential therapeutic effects. J. Agric. Food Chem. 2014, 62, 1449-1455. [CrossRef] [PubMed]

29. Barbaro, B.; Toietta, G.; Maggio, R.; Arciello, M.; Tarocchi, M.; Galli, A.; Balsano, C. Effects of the olive-derived polyphenol oleuropein on human health. Int. J. Mol. Sci. 2014, 15, 18508-18524. [CrossRef]

30. Khalatbary, A.R. Olive oil phenols and neuroprotection. Nutr. Neurosci. 2013, 16, 243-249. [CrossRef]

31. Sofi, F.; Cesari, F.; Abbate, R.; Gensini, G.F.; Casini, A. Adherence to Mediterranean diet and health status: Meta-analysis. BMJ 2008, 337, a1344. [CrossRef] [PubMed]

32. Dinu, M.; Pagliai, G.; Casini, A.; Sofi, F. Mediterranean diet and multiple health outcomes: An umbrella review of meta-analyses of observational studies and randomised trials. Eur. J. Clin. Nutr. 2018, 72, 30-43. [CrossRef]

33. de Pablos, R.M.; Espinosa-Oliva, A.M.; Hornedo-Ortega, R.; Cano, M.; Arguelles, S. Hydroxytyrosol protects from aging process via AMPK and autophagy; a review of its effects on cancer, metabolic syndrome, osteoporosis, immune-mediated and neurodegenerative diseases. Pharmacol. Res. 2019, 143, 58-72. [CrossRef] [PubMed]

34. George, E.S.; Marshall, S.; Mayr, H.L.; Trakman, G.L.; Tatucu-Babet, O.A.; Lassemillante, A.-C.M.; Bramley, A.; Reddy, A.J.; Forsyth, A.; Tierney, A.C. The effect of high-polyphenol extra virgin olive oil on cardiovascular risk factors: A systematic review and meta-analysis. Crit. Rev. Food Sci. Nutr. 2019, 59, 2772-2795. [CrossRef]

35. Servili, M.; Esposto, S.; Fabiani, R.; Urbani, S.; Taticchi, A.; Mariucci, F.; Selvaggini, R.; Montedoro, G. Phenolic compounds in olive oil: Antioxidant, health and organoleptic activities according to their chemical structure. Inflammopharmacology 2009, 17, 76-84. [CrossRef]

36. Nazzaro, F.; Fratianni, F.; Cozzolino, R.; Martignetti, A.; Malorni, L.; De Feo, V.; Cruz, A.G.; d'Acierno, A. Antibacterial activity of three extra virgin olive oils of the Campania region, Southern Italy, related to their polyphenol content and composition Microorganisms 2019, 7, 321. [CrossRef] [PubMed] 
37. Schwingshackl, L.; Hoffmann, G. Adherence to Mediterranean diet and risk of cancer: An updated systematic review and meta-analysis of observational studies. Cancer Med. 2015, 4, 1933-1947. [CrossRef] [PubMed]

38. Trichopoulou, A.; Lagiou, P.; Kuper, H.; Trichopoulos, D. Cancer and Mediterranean dietary traditions. Cancer Epidemiol. Prev. Biomark. 2000, 9, 869-873.

39. Bosetti, C.; Pelucchi, C.; La Vecchia, C. Diet and cancer in Mediterranean countries: Carbohydrates and fats. Public Health Nutr. 2009, 12, 1595-1600. [CrossRef]

40. Mantovani, A.; Allavena, P.; Sica, A.; Balkwill, F. Cancer-related inflammation. Nature 2008, 454, 436-444. [CrossRef]

41. Hanahan, D.; Weinberg, R.A. Hallmarks of cancer: The next generation. Cell 2011, 144, 646-674. [CrossRef]

42. Ostan, R.; Lanzarini, C.; Pini, E.; Scurti, M.; Vianello, D.; Bertarelli, C.; Fabbri, C.; Izzi, M.; Palmas, G.; Biondi, F. Inflammaging and cancer: A challenge for the Mediterranean diet. Nutrients 2015, 7, 2589-2621. [CrossRef]

43. Bifulco, M. Mediterranean diet: The missing link between gut microbiota and inflammatory diseases. Eur. J. Clin. Nutr. 2015, 69, 1078. [CrossRef]

44. Gorzynik-Debicka, M.; Przychodzen, P.; Cappello, F.; Kuban-Jankowska, A.; Marino Gammazza, A.; Knap, N.; Wozniak, M.; Gorska-Ponikowska, M. Potential health benefits of olive oil and plant polyphenols. Int. J. Mol. Sci. 2018, 19, 686. [CrossRef] [PubMed]

45. Psaltopoulou, T.; Kosti, R.I.; Haidopoulos, D.; Dimopoulos, M.; Panagiotakos, D.B. Olive oil intake is inversely related to cancer prevalence: A systematic review and a meta-analysis of 13,800 patients and 23,340 controls in 19 observational studies. Lipids Health Dis. 2011, 10, 1-16. [CrossRef]

46. Pelucchi, C.; Bosetti, C.; Negri, E.; Lipworth, L.; La Vecchia, C. Olive oil and cancer risk: An update of epidemiological findings through 2010. Curr. Pharm. Des. 2011, 17, 805-812. [CrossRef]

47. Xin, Y.; Li, X.-Y.; Sun, S.-R.; Wang, L.-X.; Huang, T. Vegetable oil intake and breast cancer risk: A meta-analysis. Asian Pac. J. Cancer Prev. 2015, 16, 5125-5135. [CrossRef] [PubMed]

48. Colomer, R.; Menéndez, J.A. Mediterranean diet, olive oil and cancer. Clin. Transl. Oncol. 2006, 8, 15-21. [CrossRef]

49. Ferlay, J.; Colombet, M.; Soerjomataram, I.; Parkin, D.M.; Piñeros, M.; Znaor, A.; Bray, F. Cancer statistics for the year 2020: An overview. Int. J. Cancer 2021. [CrossRef] [PubMed]

50. Torre, L.A.; Bray, F.; Siegel, R.L.; Ferlay, J.; Lortet-Tieulent, J.; Jemal, A. Global cancer statistics, 2012. CA Cancer J. Clin. 2015, 65, 87-108. [CrossRef]

51. Stenzel, A.E.; Buas, M.F.; Moysich, K.B. Survival disparities among racial/ethnic groups of women with ovarian cancer: An update on data from the Surveillance, Epidemiology and End Results (SEER) registry. Cancer Epidemiol. 2019, $62,101580$. [CrossRef] [PubMed]

52. Benot-Dominguez, R.; Tupone, M.G.; Castelli, V.; d'Angelo, M.; Benedetti, E.; Quintiliani, M.; Cinque, B.; Forte, I.M.; Cifone, M.G.; Ippoliti, R. Olive leaf extract impairs mitochondria by pro-oxidant activity in MDA-MB-231 and OVCAR-3 cancer cells. Biomed. Pharmacother. 2021, 134, 111139. [CrossRef]

53. Shabani, S.H.S.; Amini-Farsani, Z.; Rahmati, S.; Jazaieri, A.; Mohammadi-Samani, M.; Asgharzade, S. Oleuropein reduces cisplatin resistance in ovarian cancer by targeting apoptotic pathway regulators. Life Sci. 2021, 278, 119525.

54. Fields, E.C.; McGuire, W.P.; Lin, L.; Temkin, S.M. Radiation treatment in women with ovarian cancer: Past, present, and future. Front. Oncol. 2017, 7, 177. [CrossRef]

55. Xing, Y.; Cui, D.; Wang, S.; Wang, P.; Xing, X.; Li, H. Oleuropein represses the radiation resistance of ovarian cancer by inhibiting hypoxia and microRNA-299-targetted heparanase expression. Food Funct. 2017, 8, 2857-2864. [CrossRef]

56. Shindoh, M.; Higashino, F.; Kohgo, T. E1AF, an ets-oncogene family transcription factor. Cancer Lett. 2004, 216, 1-8. [CrossRef] [PubMed]

57. Chotteau-Lelièvre, A.; Desbiens, X.; Pelczar, H.; Defossez, P.-A.; de Launoit, Y. Differential expression patterns of the PEA3 group transcription factors through murine embryonic development. Oncogene 1997, 15, 937-952. [CrossRef]

58. Chotteau-Lelievre, A.; Montesano, R.; Soriano, J.; Soulie, P.; Desbiens, X.; De Launoit, Y. PEA3 transcription factors are expressed in tissues undergoing branching morphogenesis and promote formation of duct-like structures by mammary epithelial cells in vitro. Dev. Biol. 2003, 259, 241-257. [CrossRef]

59. Zhang, Z.; Verheyden, J.M.; Hassell, J.A.; Sun, X. FGF-regulated Etv genes are essential for repressing Shh expression in mouse limb buds. Dev. Cell 2009, 16, 607-613. [CrossRef] [PubMed]

60. Xing, X.; Wang, S.-C.; Xia, W.; Zou, Y.; Shao, R.; Kwong, K.Y.; Yu, Z.; Zhang, S.; Miller, S.; Huang, L. The ets protein PEA3 suppresses HER-2/neu overexpression and inhibits tumorigenesis. Nat. Med. 2000, 6, 189-195. [CrossRef] [PubMed]

61. Wang, S.-C.; Hung, M.-C. Transcriptional targeting of the HER-2/neu oncogene. Drugs Today (Barc.) 2000, 36, 835-843.

62. Menendez, J.A.; Papadimitropoulou, A.; Vellon, L.; Lupu, R. A genomic explanation connecting "Mediterranean diet", olive oil and cancer: Oleic acid, the main monounsaturated fatty acid of olive oil, induces formation of inhibitory "PEA3 transcription factor-PEA3 DNA binding site" complexes at the Her-2/neu (erbB-2) oncogene promoter in breast, ovarian and stomach cancer cells. Eur. J. Cancer 2006, 42, 2425-2432. [PubMed]

63. Tzonou, A.; Hsieh, C.C.; Polychronopoulou, A.; Trichopoulos, D.; Kaprinis, G.; Toupadaki, N.; Karakatsani, A.; Trichopoulou, A. Diet and ovarian cancer: A case-control study in Greece. Int. J. Cancer 1993, 55, 411-414. [CrossRef]

64. Bosetti, C.; Negri, E.; Franceschi, S.; Talamini, R.; Montella, M.; Conti, E.; Lagiou, P.; Parazzini, F.; La Vecchia, C. Olive oil, seed oils and other added fats in relation to ovarian cancer (Italy). Cancer Causes Control 2002, 13, 465-470. [CrossRef] [PubMed] 
65. Hu, C.; Hart, S.N.; Gnanaolivu, R.; Huang, H.; Lee, K.Y.; Na, J.; Gao, C.; Lilyquist, J.; Yadav, S.; Boddicker, N.J. A population-based study of genes previously implicated in breast cancer. N. Engl. J. Med. 2021, 384, 440-451. [CrossRef] [PubMed]

66. Siegel, R.L.; Miller, K.D.; Fuchs, H.E.; Jemal, A. Cancer statistics, 2021. CA Cancer J. Clin. 2021, 71, 7-33. [CrossRef] [PubMed]

67. Korde, L.A.; Somerfield, M.R.; Carey, L.A.; Crews, J.R.; Denduluri, N.; Hwang, E.S.; Khan, S.A.; Loibl, S.; Morris, E.A.; Perez, A. Neoadjuvant chemotherapy, endocrine therapy, and targeted therapy for breast cancer: ASCO guideline. J. Clin. Oncol. Off. J. Am. Soc. Clin. Oncol. 2021, 39, 1485-1505. [CrossRef] [PubMed]

68. Early Breast Cancer Trialists' Collaborative Group; Peto, R.; Davies, C.; Godwin, J.; Gray, R.; Pan, H.C.; Clarke, M.; Cutter, D.; Darby, S.; McGale, P.; et al. Comparisons between different polychemotherapy regimens for early breast cancer: Meta-analyses of long-term outcome among 100,000 women in 123 randomised trials. Lancet 2012, 379, 432-444. [PubMed]

69. Early Breast Cancer Trialists' Collaborative Group; Darby, S.; McGale, P.; Correa, C.; Taylor, C.; Arriagada, R.; Clarke, M.; Cutter, D.; Davies, C.; Ewertz, M.; et al. Effect of radiotherapy after breast-conserving surgery on 10-year recurrence and 15-year breast cancer death: Meta-analysis of individual patient data for 10801 women in 17 randomised trials. Lancet 2011, 378, $1707-1716$

70. Forouzanfar, M.H.; Foreman, K.J.; Delossantos, A.M.; Lozano, R.; Lopez, A.D.; Murray, C.J.; Naghavi, M. Breast and cervical cancer in 187 countries between 1980 and 2010: A systematic analysis. Lancet 2011, 378, 1461-1484. [CrossRef]

71. Escrich, E.; Moral, R.; Solanas, M. Olive oil, an essential component of the Mediterranean diet, and breast cancer. Public Health Nutr. 2011, 14, 2323-2332. [CrossRef]

72. Escrich, E.; Solanas, M.; Moral, R.; Escrich, R. Modulatory effects and molecular mechanisms of olive oil and other dietary lipids in breast cancer. Curr. Pharm. Des. 2011, 17, 813-830. [CrossRef] [PubMed]

73. Casaburi, I.; Puoci, F.; Chimento, A.; Sirianni, R.; Ruggiero, C.; Avena, P.; Pezzi, V. Potential of olive oil phenols as chemopreventive and therapeutic agents against cancer: A review of in vitro studies. Mol. Nutr. Food Res. 2013, 57, 71-83. [CrossRef]

74. Toledo, E.; Salas-Salvadó, J.; Donat-Vargas, C.; Buil-Cosiales, P.; Estruch, R.; Ros, E.; Corella, D.; Fitó, M.; Hu, F.B.; Arós, F. Mediterranean diet and invasive breast cancer risk among women at high cardiovascular risk in the PREDIMED trial: A randomized clinical trial. JAMA Int. Med. 2015, 175, 1752-1760. [CrossRef] [PubMed]

75. Villarini, A.; Pasanisi, P.; Traina, A.; Mano, M.P.; Bonanni, B.; Panico, S.; Scipioni, C.; Galasso, R.; Paduos, A.; Simeoni, M. Lifestyle and breast cancer recurrences: The DIANA-5 trial. Tumori J. 2012, 98, 1-18. [CrossRef]

76. Quirantes-Piné, R.; Zurek, G.; Barrajón-Catalán, E.; Bäßmann, C.; Micol, V.; Segura-Carretero, A.; Fernández-Gutiérrez, A. A metabolite-profiling approach to assess the uptake and metabolism of phenolic compounds from olive leaves in SKBR3 cells by HPLC-ESI-QTOF-MS. J. Pharm. Biomed. Anal. 2013, 72, 121-126. [CrossRef]

77. Menendez, J.A.; Vazquez-Martin, A.; Colomer, R.; Brunet, J.; Carrasco-Pancorbo, A.; Garcia-Villalba, R.; Fernandez-Gutierrez, A.; Segura-Carretero, A. Olive oil's bitter principle reverses acquired autoresistance to trastuzumab (Herceptin ${ }^{\mathrm{TM}}$ ) in HER2overexpressing breast cancer cells. BMC Cancer 2007, 7, 80. [CrossRef]

78. Han, J.; Talorete, T.P.; Yamada, P.; Isoda, H. Anti-proliferative and apoptotic effects of oleuropein and hydroxytyrosol on human breast cancer MCF-7 cells. Cytotechnology 2009, 59, 45-53. [CrossRef] [PubMed]

79. Asgharzade, S.; Sheikhshabani, S.H.; Ghasempour, E.; Heidari, R.; Rahmati, S.; Mohammadi, M.; Jazaeri, A.; Amini-Farsani, Z. The effect of oleuropein on apoptotic pathway regulators in breast cancer cells. Eur. J. Pharmacol. 2020, 886, 173509. [CrossRef]

80. Reboredo-Rodríguez, P.; González-Barreiro, C.; Cancho-Grande, B.; Forbes-Hernández, T.Y.; Gasparrini, M.; Afrin, S.; Cianciosi, D.; Carrasco-Pancorbo, A.; Simal-Gándara, J.; Giampieri, F. Characterization of phenolic extracts from Brava extra virgin olive oils and their cytotoxic effects on MCF-7 breast cancer cells. Food Chem. Toxicol. 2018, 119, 73-85. [CrossRef]

81. Bayat, S.; Mansoori Derakhshan, S.; Mansoori Derakhshan, N.; Shekari Khaniani, M.; Alivand, M.R. Downregulation of HDAC2 and HDAC3 via oleuropein as a potent prevention and therapeutic agent in MCF-7 breast cancer cells. J. Cell. Biochem. 2019, 120, 9172-9180. [CrossRef] [PubMed]

82. Messeha, S.S.; Zarmouh, N.O.; Asiri, A.; Soliman, K.F. Gene Expression Alterations Associated with Oleuropein-Induced Antiproliferative Effects and S-Phase Cell Cycle Arrest in Triple-Negative Breast Cancer Cells. Nutrients 2020, 12, 3755. [CrossRef]

83. Hassan, Z.K.; Elamin, M.H.; Omer, S.A.; Daghestani, M.H.; Al-Olayan, E.S.; Elobeid, M.A.; Virk, P. Oleuropein induces apoptosis via the p53 pathway in breast cancer cells. Asian Pac. J. Cancer Prev. 2013, 14, 6739-6742. [CrossRef]

84. Mazzei, R.; Piacentini, E.; Nardi, M.; Poerio, T.; Bazzarelli, F.; Procopio, A.; Di Gioia, M.L.; Rizza, P.; Ceraldi, R.; Morelli, C. Production of plant-derived oleuropein aglycone by a combined membrane process and evaluation of its breast anticancer properties. Front. Bioeng. Biotechnol. 2020, 8, 908. [CrossRef]

85. Elamin, M.H.; Daghestani, M.H.; Omer, S.A.; Elobeid, M.A.; Virk, P.; Al-Olayan, E.M.; Hassan, Z.K.; Mohammed, O.B.; Aboussekhra, A. Olive oil oleuropein has anti-breast cancer properties with higher efficiency on ER-negative cells. Food Chem. Toxicol. 2013, 53, 310-316. [CrossRef] [PubMed]

86. Akalay, I.; Janji, B.; Hasmim, M.; Noman, M.Z.; Thiery, J.P.; Mami-Chouaib, F.; Chouaib, S. EMT impairs breast carcinoma cell susceptibility to CTL-mediated lysis through autophagy induction. Autophagy 2013, 9, 1104-1106. [CrossRef] [PubMed]

87. Chua, K.-N.; Sim, W.-J.; Racine, V.; Lee, S.-Y.; Goh, B.C.; Thiery, J.P. A cell-based small molecule screening method for identifying inhibitors of epithelial-mesenchymal transition in carcinoma. PLoS ONE 2012, 7, e33183. [CrossRef] [PubMed]

88. Choupani, J.; Alivand, M.R.; Derakhshan, S.M.; Zaeifizadeh, M.; Khaniani, M.S. Oleuropein inhibits migration ability through suppression of epithelial-mesenchymal transition and synergistically enhances doxorubicin-mediated apoptosis in MCF-7 cells. J. Cell. Physiol. 2019, 234, 9093-9104. [CrossRef] [PubMed] 
89. Bouallagui, Z.; Han, J.; Isoda, H.; Sayadi, S. Hydroxytyrosol rich extract from olive leaves modulates cell cycle progression in MCF-7 human breast cancer cells. Food Chem. Toxicol. 2011, 49, 179-184. [CrossRef]

90. Lu, H.-Y.; Zhu, J.-S.; Xie, J.; Zhang, Z.; Zhu, J.; Jiang, S.; Shen, W.-J.; Wu, B.; Ding, T.; Wang, S.-L. Hydroxytyrosol and oleuropein inhibit migration and invasion via induction of autophagy in ER-positive breast cancer cell lines (MCF7 and T47D). Nutr. Cancer 2021, 73, 350-360. [CrossRef]

91. Mansouri, N.; Alivand, M.R.; Bayat, S.; Khaniani, M.S.; Derakhshan, S.M. The hopeful anticancer role of oleuropein in breast cancer through histone deacetylase modulation. J. Cell. Biochem. 2019, 120, 17042-17049. [CrossRef]

92. Sirianni, R.; Chimento, A.; De Luca, A.; Casaburi, I.; Rizza, P.; Onofrio, A.; Iacopetta, D.; Puoci, F.; Andò, S.; Maggiolini, M. Oleuropein and hydroxytyrosol inhibit MCF-7 breast cancer cell proliferation interfering with ERK1/2 activation. Mol. Nutr. Food Res. 2010, 54, 833-840. [CrossRef]

93. Qusa, M.H.; Abdelwahed, K.S.; Siddique, A.B.; El Sayed, K.A. Comparative Gene Signature of (-)-Oleocanthal Formulation Treatments in Heterogeneous Triple Negative Breast Tumor Models: Oncological Therapeutic Target Insights. Nutrients 2021, 13, 1706. [CrossRef]

94. Liao, S.-C.; Li, J.-X.; Yu, L.; Sun, S.-R. Protein tyrosine phosphatase 1B expression contributes to the development of breast cancer. J. Zhejiang Univ. -Sci. B 2017, 18, 334-342. [CrossRef] [PubMed]

95. Liu, X.; Chen, Q.; Hu, X.-G.; Zhang, X.-C.; Fu, T.-W.; Liu, Q.; Liang, Y.; Zhao, X.-L.; Zhang, X.; Ping, Y.-F. PTP1B promotes aggressiveness of breast cancer cells by regulating PTEN but not EMT. Tumor Biol. 2016, 37, 13479-13487. [CrossRef] [PubMed]

96. Przychodzen, P.; Kuban-Jankowska, A.; Wyszkowska, R.; Barone, G.; Bosco, G.L.; Celso, F.L.; Kamm, A.; Daca, A.; Kostrzewa, T.; Gorska-Ponikowska, M. PTP1B phosphatase as a novel target of oleuropein activity in MCF-7 breast cancer model. Toxicol. Vitr. 2019, 61, 104624. [CrossRef] [PubMed]

97. Harari, D.; Yarden, Y. Molecular mechanisms underlying ErbB2/HER2 action in breast cancer. Oncogene 2000, $19,6102-6114$. [CrossRef] [PubMed]

98. Yarden, Y. Biology of HER2 and its importance in breast cancer. Oncology 2001, 61, 1-13. [CrossRef] [PubMed]

99. Nahta, R.; Yu, D.; Hung, M.-C.; Hortobagyi, G.N.; Esteva, F.J. Mechanisms of disease: Understanding resistance to HER2-targeted therapy in human breast cancer. Nat. Clin. Pract. Oncol. 2006, 3, 269-280. [CrossRef]

100. Menendez, J.A.; Vazquez-Martin, A.; Garcia-Villalba, R.; Carrasco-Pancorbo, A.; Oliveras-Ferraros, C.; Fernandez-Gutierrez, A.; Segura-Carretero, A. tabAnti-HER2 (erb B-2) oncogene effects of phenolic compounds directly isolated from commercial Extra-Virgin Olive Oil (EVOO). BMC Cancer 2008, 8, 377. [CrossRef]

101. Menendez, J.A.; Vazquez-Martin, A.; Oliveras-Ferraros, C.; Garcia-Villalba, R.; Carrasco-Pancorbo, A.; Fernandez-Gutierrez, A.; Segura-Carretero, A. Analyzing effects of extra-virgin olive oil polyphenols on breast cancer-associated fatty acid synthase protein expression using reverse-phase protein microarrays. Int. J. Mol. Med. 2008, 22, 433-439. [CrossRef]

102. Menendez, J.A.; Lupu, R. Fatty acid synthase and the lipogenic phenotype in cancer pathogenesis. Nat. Rev. Cancer 2007, 7, 763-777. [CrossRef]

103. Hassan, Z.K.; Elamin, M.H.; Daghestani, M.H.; Omer, S.A.; Al-Olayan, E.M.; Elobeid, M.A.; Virk, P.; Mohammed, O.B. Oleuropein induces anti-metastatic effects in breast cancer. Asian Pac. J. Cancer Prev. 2012, 13, 4555-4559. [CrossRef]

104. Lapierre, M.; Linares, A.; Dalvai, M.; Duraffourd, C.; Bonnet, S.; Boulahtouf, A.; Rodriguez, C.; Jalaguier, S.; Assou, S.; Orsetti, B. Histone deacetylase 9 regulates breast cancer cell proliferation and the response to histone deacetylase inhibitors. Oncotarget 2016, 7, 19693. [CrossRef]

105. Senese, S.; Zaragoza, K.; Minardi, S.; Muradore, I.; Ronzoni, S.; Passafaro, A.; Bernard, L.; Draetta, G.F.; Alcalay, M.; Seiser, C. Role for histone deacetylase 1 in human tumor cell proliferation. Mol. Cell. Biol. 2007, 27, 4784-4795. [CrossRef]

106. Duffy, M.J.; McGowan, P.M.; Harbeck, N.; Thomssen, C.; Schmitt, M. uPA and PAI-1 as biomarkers in breast cancer: Validated for clinical use in level-of-evidence-1 studies. Breast Cancer Res. 2014, 16, 428. [CrossRef]

107. Ferroni, P.; Roselli, M.; Portarena, I.; Formica, V.; Riondino, S.; La Farina, F.; Costarelli, L.; Melino, A.; Massimiani, G.; Cavaliere, F. Plasma plasminogen activator inhibitor-1 (PAI-1) levels in breast cancer-relationship with clinical outcome. Anticancer Res. 2014, 34, 1153-1161. [PubMed]

108. Tzekaki, E.E.; Geromichalos, G.; Lavrentiadou, S.N.; Tsantarliotou, M.P.; Pantazaki, A.A.; Papaspyropoulos, A. Oleuropein is a natural inhibitor of PAI-1-mediated proliferation in human ER-/PR-breast cancer cells. Breast Cancer Res. Treat. 2021, 186, 305-316. [CrossRef]

109. Chaffer, C.L.; Weinberg, R.A. How does multistep tumorigenesis really proceed? Cancer Discov. 2015, 5, 22-24. [CrossRef] [PubMed]

110. Magee, J.A.; Piskounova, E.; Morrison, S.J. Cancer stem cells: Impact, heterogeneity, and uncertainty. Cancer Cell 2012, 21, 283-296. [CrossRef]

111. Kakarala, M.; Wicha, M.S. Implications of the cancer stem-cell hypothesis for breast cancer prevention and therapy. J. Clin. Oncol. Off. J. Am. Soc. Clin. Oncol. 2008, 26, 2813. [CrossRef]

112. Corominas-Faja, B.; Cuyàs, E.; Lozano-Sánchez, J.; Cufí, S.; Verdura, S.; Fernández-Arroyo, S.; Borrás-Linares, I.; Martin-Castillo, B.; Martin, Á.G.; Lupu, R. Extra-virgin olive oil contains a metabolo-epigenetic inhibitor of cancer stem cells. Carcinogenesis 2018, 39, 601-613. [CrossRef] 
113. Skouroliakou, M.; Grosomanidis, D.; Massara, P.; Kostara, C.; Papandreou, P.; Ntountaniotis, D.; Xepapadakis, G. Serum antioxidant capacity, biochemical profile and body composition of breast cancer survivors in a randomized Mediterranean dietary intervention study. Eur. J. Nutr. 2018, 57, 2133-2145. [CrossRef]

114. Martínez, N.; Herrera, M.; Frías, L.; Provencio, M.; Pérez-Carrión, R.; Díaz, V.; Morse, M.; Crespo, M. A combination of hydroxytyrosol, omega-3 fatty acids and curcumin improves pain and inflammation among early stage breast cancer patients receiving adjuvant hormonal therapy: Results of a pilot study. Clin. Transl. Oncol. 2019, 21, 489-498. [CrossRef]

115. Lipworth, L.; Martínez, M.E.; Angell, J.; Hsieh, C.-C.; Trichopoulos, D. Olive oil and human cancer: An assessment of the evidence. Prev. Med. 1997, 26, 181-190. [CrossRef] [PubMed]

116. Sealy, N.; Hankinson, S.E.; Houghton, S.C. Olive oil and risk of breast cancer: A systematic review and dose-response metaanalysis of observational studies. Br. J. Nutr. 2021, 125, 1148-1156. [CrossRef]

117. Bray, F.; Ferlay, J.; Soerjomataram, I.; Siegel, R.L.; Torre, L.A.; Jemal, A. Global cancer statistics 2018: GLOBOCAN estimates of incidence and mortality worldwide for 36 cancers in 185 countries. CA Cancer J. Clin. 2018, 68, 394-424. [CrossRef]

118. Sung, H.; Ferlay, J.; Siegel, R.L.; Laversanne, M.; Soerjomataram, I.; Jemal, A.; Bray, F. Global cancer statistics 2020: GLOBOCAN estimates of incidence and mortality worldwide for 36 cancers in 185 countries. CA Cancer J. Clin. 2021, 71, 209-249. [CrossRef]

119. Walboomers, J.M.; Jacobs, M.V.; Manos, M.M.; Bosch, F.X.; Kummer, J.A.; Shah, K.V.; Snijders, P.J.; Peto, J.; Meijer, C.J.; Muñoz, N. Human papillomavirus is a necessary cause of invasive cervical cancer worldwide. J. Pathol. 1999, 189, 12-19. [CrossRef]

120. Torić, J.; Brozovic, A.; Baus Lončar, M.; Jakobušić Brala, C.; Karković Marković, A.; Benčić, Đ.; Barbarić, M. Biological activity of phenolic compounds in extra virgin olive oils through their phenolic profile and their combination with anticancer drugs observed in human cervical carcinoma and colon adenocarcinoma cells. Antioxidants 2020, 9, 453. [CrossRef]

121. Kouka, P.; Tsakiri, G.; Tzortzi, D.; Dimopoulou, S.; Sarikaki, G.; Stathopoulos, P.; Veskoukis, A.S.; Halabalaki, M.; Skaltsounis, A.L.; Kouretas, D. The Polyphenolic Composition of Extracts Derived from Different Greek Extra Virgin Olive Oils Is Correlated with Their Antioxidant Potency. Oxid. Med. Cell. Longev. 2019, 2019, 1870965. [CrossRef] [PubMed]

122. Barchitta, M.; Maugeri, A.; Quattrocchi, A.; Agrifoglio, O.; Scalisi, A.; Agodi, A. The association of dietary patterns with high-risk human papillomavirus infection and cervical cancer: A cross-sectional study in Italy. Nutrients 2018, 10, 469. [CrossRef] [PubMed]

123. Yao, J.; Wu, J.; Yang, X.; Yang, J.; Zhang, Y.; Du, L. Oleuropein induced apoptosis in HeLa cells via a mitochondrial apoptotic cascade associated with activation of the c-Jun NH2-terminal kinase. J. Pharmacol. Sci. 2014, 125, 300-311. [CrossRef]

124. Yang, P.; Su, C.; Luo, X.; Zeng, H.; Zhao, L.; Wei, L.; Zhang, X.; Varghese, Z.; Moorhead, J.F.; Chen, Y. Dietary oleic acid-induced CD36 promotes cervical cancer cell growth and metastasis via up-regulation Src/ERK pathway. Cancer Lett. 2018, 438, 76-85. [CrossRef] [PubMed]

125. Zhang, X.; Yang, P.; Luo, X.; Su, C.; Chen, Y.; Zhao, L.; Wei, L.; Zeng, H.; Varghese, Z.; Moorhead, J.F.; et al. High olive oil diets enhance cervical tumour growth in mice: Transcriptome analysis for potential candidate genes and pathways. Lipids Health Dis. 2019, 18, 76. [CrossRef]

126. Way, S. Vaginal metastases of carcinoma of the body of the uterus. BJOG Int. J. Obstet. Gynaecol. 1951, 58, 558-572. [CrossRef] [PubMed]

127. Benedet, J.; Pecorelli, S.; Ngan, H.; Hacker, N.F.; Denny, L.; Jones, H.W., III; Kavanagh, J.; Kitchener, H.; Kohorn, E.; Thomas, G. Staging classifications and clinical practice guidelines for gynaecological cancers. Int. J. Gynecol. Obstet. 2000, 70, $207-312$. [CrossRef]

128. Bokhman, J.V. Two pathogenetic types of endometrial carcinoma. Gynecol. Oncol. 1983, 15, 10-17. [CrossRef]

129. Lian, J.; Dundas, G.; Carlone, M.; Ghosh, S.; Pearcey, R. Twenty-year review of radiotherapy for vaginal cancer: An institutional experience. Gynecol. Oncol. 2008, 111, 298-306. [CrossRef] [PubMed]

130. Dunn, L.J.; Napier, J.G. Primary carcinoma of the vagina. Am. J. Obstet. Gynecol. 1966, 96, 1112-1116. [CrossRef]

131. Berek, J.S.; Karam, A.; Dizon, D.S. Vulvar Cancer: Epidemiology, Diagnosis, Histopathology, and Treatment; Goff, B., Dizon, D.S., Eds.; UpToDate: Waltham, MA, USA, 2020.

132. Saraiya, M.; Watson, M.; Wu, X.; King, J.B.; Chen, V.W.; Smith, J.S.; Giuliano, A.R. Incidence of in situ and invasive vulvar cancer in the US, 1998-2003. Cancer 2008, 113, 2865-2872. [CrossRef]

133. Schuurman, M.; Van Den Einden, L.; Massuger, L.F.; Kiemeney, L.; van der Aa, M.A.; de Hullu, J.A. Trends in incidence and survival of Dutch women with vulvar squamous cell carcinoma. Eur. J. Cancer 2013, 49, 3872-3880. [CrossRef]

134. Walker, B.E.; Edwards, S.N. Reproductive system tumors in mice exposed to various types of fat perinatally. Anticancer Res. 2003, 23, 4689-4691.

135. Nelson, H.D. Menopause. Lancet 2008, 371, 760-770. [CrossRef]

136. Nappi, R.E.; Simoncini, T. Menopause transition: A golden age to prevent cardiovascular disease. Lancet Diabetes Endocrinol. 2021, 9, 135-137. [CrossRef]

137. Liu, H.; Huang, H.; Li, B.; Wu, D.; Wang, F.; Zheng, X.h.; Chen, Q.; Wu, B.; Fan, X. Olive oil in the prevention and treatment of osteoporosis after artificial menopause. Clin. Interv. Aging 2014, 9, 2087. [CrossRef]

138. Vignini, A.; Nanetti, L.; Raffaelli, F.; Sabbatinelli, J.; Salvolini, E.; Quagliarini, V.; Cester, N.; Mazzanti, L. Effect of 1-y oral supplementation with vitaminized olive oil on platelets from healthy postmenopausal women. Nutrition 2017, 42, 92-98. [CrossRef] [PubMed] 
139. Salvini, S.; Sera, F.; Caruso, D.; Giovannelli, L.; Visioli, F.; Saieva, C.; Masala, G.; Ceroti, M.; Giovacchini, V.; Pitozzi, V. Daily consumption of a high-phenol extra-virgin olive oil reduces oxidative DNA damage in postmenopausal women. Br. J. Nutr. 2006, 95, 742-751. [CrossRef] [PubMed]

140. Rezaeyan, M.; Khedri, P.; Direkvand-Moghadam, A. The Impact of Nutritional Supplement on Reducing the Symptoms of Primary Dysmenorrhea in Comparison to the Classical Anti-Inflammatory Treatment; A Sequential Self Case-Controlled Study. Women's Health Gynecol. 2017, 5, 2.

141. Juraskova, I.; Jarvis, S.; Mok, K.; Peate, M.; Meiser, B.; Cheah, B.C.; Mireskandari, S.; Friedlander, M. The Acceptability, Feasibility, and Efficacy (P hase I/II Study) of the OVER come (O live Oil, V aginal E xercise, and Moisturize R) Intervention to Improve Dyspareunia and Alleviate Sexual Problems in Women with Breast Cancer. J. Sex. Med. 2013, 10, 2549-2558. [CrossRef]

142. Lorentzon, M.; Johansson, H.; Harvey, N.; Liu, E.; Vandenput, L.; McCloskey, E.; Kanis, J. Osteoporosis and fractures in women: The burden of disease. Climacteric 2021, 1-7. [CrossRef]

143. Chin, K.-Y.; Ima-Nirwana, S. Olives and bone: A green osteoporosis prevention option. Int. J. Environ. Res. Public Health 2016, 13, 755. [CrossRef]

144. Hagiwara, K.; Goto, T.; Araki, M.; Miyazaki, H.; Hagiwara, H. Olive polyphenol hydroxytyrosol prevents bone loss. Eur. J. Pharmacol. 2011, 662, 78-84. [CrossRef]

145. Puel, C.; Mardon, J.; Agalias, A.; Davicco, M.-J.; Lebecque, P.; Mazur, A.; Horcajada, M.-N.; Skaltsounis, A.-L.; Coxam, V. Major phenolic compounds in olive oil modulate bone loss in an ovariectomy/inflammation experimental model. J. Agric. Food Chem. 2008, 56, 9417-9422. [CrossRef]

146. Puel, C.; Mardon, J.; Kati-Coulibaly, S.; Davicco, M.-J.; Lebecque, P.; Obled, C.; Rock, E.; Horcajada, M.-N.; Agalias, A.; Skaltsounis, L.A. Black Lucques olives prevented bone loss caused by ovariectomy and talc granulomatosis in rats. Br. J. Nutr. 2007, 97, 1012-1020. [CrossRef]

147. Puel, C.; Quintin, A.; Agalias, A.; Mathey, J.; Obled, C.; Mazur, A.; Davicco, M.; Lebecque, P.; Skaltsounis, A.; Coxam, V. Olive oil and its main phenolic micronutrient (oleuropein) prevent inflammation-induced bone loss in the ovariectomised rat. Br. J. Nutr. 2004, 92, 119-127. [CrossRef]

148. Puel, C.; Mathey, J.; Agalias, A.; Kati-Coulibaly, S.; Mardon, J.; Obled, C.; Davicco, M.-J.; Lebecque, P.; Horcajada, M.-N.; Skaltsounis, A.L. Dose-response study of effect of oleuropein, an olive oil polyphenol, in an ovariectomy/inflammation experimental model of bone loss in the rat. Clin. Nutr. 2006, 25, 859-868. [CrossRef]

149. Saleh, N.K.; Saleh, H.A. Olive oil effectively mitigates ovariectomy-induced osteoporosis in rats. BMC Complement. Altern. Med. 2011, 11, 10. [CrossRef]

150. Santiago-Mora, R.; Casado-Díaz, A.; De Castro, M.; Quesada-Gómez, J. Oleuropein enhances osteoblastogenesis and inhibits adipogenesis: The effect on differentiation in stem cells derived from bone marrow. Osteoporos. Int. 2011, 22, 675-684. [CrossRef]

151. García-Martínez, O.; De Luna-Bertos, E.; Ramos-Torrecillas, J.; Ruiz, C.; Milia, E.; Lorenzo, M.L.; Jimenez, B.; Sánchez-Ortiz, A.; Rivas, A. Phenolic compounds in extra virgin olive oil stimulate human osteoblastic cell proliferation. PLoS ONE 2016, 11, e0150045. [CrossRef]

152. Claassen, N.; Potgieter, H.; Seppa, M.; Vermaak, W.; Coetzer, H.; Van Papendorp, D.; Kruger, M. Supplemented gamma-linolenic acid and eicosapentaenoic acid influence bone status in young male rats: Effects on free urinary collagen crosslinks, total urinary hydroxyproline, and bone calcium content. Bone 1995, 16, S385-S392. [CrossRef]

153. Filip, R.; Possemiers, S.; Heyerick, A.; Pinheiro, I.; Raszewski, G.; Davicco, M.-J.; Coxam, V. Twelve-month consumption of a polyphenol extract from olive (Olea europaea) in a double blind, randomized trial increases serum total osteocalcin levels and improves serum lipid profiles in postmenopausal women with osteopenia. J. Nutr. Health Aging 2015, 19, 77-86. [CrossRef]

154. Keiler, A.M.; Zierau, O.; Bernhardt, R.; Scharnweber, D.; Lemonakis, N.; Termetzi, A.; Skaltsounis, L.; Vollmer, G.; Halabalaki, M. Impact of a functionalized olive oil extract on the uterus and the bone in a model of postmenopausal osteoporosis. Eur. J. Nutr. 2014, 53, 1073-1081. [CrossRef]

155. Gryszczyńska, A.; Gryszczyńska, B.; Opala, B. The leaves of european olive (Olea europaea L.)-chemistry and application in medicine. Postępy Fitoter. 2010, 11, 30-37.

156. Susalit, E.; Agus, N.; Effendi, I.; Tjandrawinata, R.R.; Nofiarny, D.; Perrinjaquet-Moccetti, T.; Verbruggen, M. Olive (Olea europaea) leaf extract effective in patients with stage-1 hypertension: Comparison with Captopril. Phytomedicine 2011, 18, 251-258. [CrossRef] [PubMed]

157. Perrinjaquet-Moccetti, T.; Busjahn, A.; Schmidlin, C.; Schmidt, A.; Bradl, B.; Aydogan, C. Food supplementation with an olive (Olea europaea L.) leaf extract reduces blood pressure in borderline hypertensive monozygotic twins. Phytother. Res. 2008, 22, 1239-1242. [CrossRef] [PubMed]

158. Covas, M.-I. Olive oil and the cardiovascular system. Pharmacol. Res. 2007, 55, 175-186. [CrossRef] [PubMed]

159. Ruano, J.; Lopez-Miranda, J.; Fuentes, F.; Moreno, J.A.; Bellido, C.; Perez-Martinez, P.; Lozano, A.; Gómez, P.; Jiménez, Y.; Pérez Jiménez, F. Phenolic content of virgin olive oil improves ischemic reactive hyperemia in hypercholesterolemic patients. J. Am. Coll. Cardiol. 2005, 46, 1864-1868. [CrossRef] [PubMed]

160. Jimenez-Morales, A.I.; Ruano, J.; Delgado-Lista, J.; Fernandez, J.M.; Camargo, A.; Lopez-Segura, F.; Villarraso, J.C.; FuentesJimenez, F.; Lopez-Miranda, J.; Perez-Jimenez, F. NOS3 Glu298Asp polymorphism interacts with virgin olive oil phenols to determine the postprandial endothelial function in patients with the metabolic syndrome. J. Clin. Endocrinol. Metab. 2011, 96, E1694-E1702. [CrossRef] 
161. Anderson-Vasquez, H.E.; Pérez-Martínez, P.; Fernández, P.O.; Wanden-Berghe, C. Impact of the consumption of a rich diet in butter and it replacement for a rich diet in extra virgin olive oil on anthropometric, metabolic and lipid profile in postmenopausal women. Nutr. Hosp. 2015, 31, 2561-2570. [PubMed]

162. Martinez-Gonzalez, M.A.; Dominguez, L.J.; Delgado-Rodriguez, M. Olive oil consumption and risk of CHD and/or stroke: A meta-analysis of case-control, cohort and intervention studies. Br. J. Nutr. 2014, 112, 248-259. [CrossRef]

163. Medeiros-de-Moraes, I.M.; Gonçalves-de-Albuquerque, C.F.; Kurz, A.R.; Oliveira, F.M.d.J.; Abreu, V.H.P.d.; Torres, R.C.; Carvalho, V.F.; Estato, V.; Bozza, P.T.; Sperandio, M. Omega-9 oleic acid, the main compound of olive oil, mitigates inflammation during experimental sepsis. Oxidative Med. Cell. Longev. 2018, 2018, 6053492. [CrossRef]

164. Al-Azzawie, H.F.; Alhamdani, M.-S.S. Hypoglycemic and antioxidant effect of oleuropein in alloxan-diabetic rabbits. Life Sci. 2006, 78, 1371-1377. [CrossRef]

165. Moreno-Luna, R.; Muñoz-Hernandez, R.; Miranda, M.L.; Costa, A.F.; Jimenez-Jimenez, L.; Vallejo-Vaz, A.J.; Muriana, F.J.; Villar, J.; Stiefel, P. Olive oil polyphenols decrease blood pressure and improve endothelial function in young women with mild hypertension. Am. J. Hypertens. 2012, 25, 1299-1304. [CrossRef]

166. Schwingshackl, L.; Christoph, M.; Hoffmann, G. Effects of olive oil on markers of inflammation and endothelial function-A systematic review and meta-analysis. Nutrients 2015, 7, 7651-7675. [CrossRef]

167. Lockyer, S.; Corona, G.; Yaqoob, P.; Spencer, J.P.; Rowland, I. Secoiridoids delivered as olive leaf extract induce acute improvements in human vascular function and reduction of an inflammatory cytokine: A randomised, double-blind, placebo-controlled, crossover trial. Br. J. Nutr. 2015, 114, 75-83. [CrossRef] [PubMed]

168. Schwingshackl, L.; Lampousi, A.; Portillo, M.; Romaguera, D.; Hoffmann, G.; Boeing, H. Olive oil in the prevention and management of type 2 diabetes mellitus: A systematic review and meta-analysis of cohort studies and intervention trials. Nutr. Diabetes 2017, 7, e262. [CrossRef]

169. Casado-Díaz, A.; Túnez-Fiñana, I.; Mata-Granados, J.M.; Ruiz-Méndez, M.V.; Dorado, G.; Romero-Sánchez, M.C.; NavarroValverde, C.; Quesada-Gómez, J.M. Serum from postmenopausal women treated with a by-product of olive-oil extraction process stimulates osteoblastogenesis and inhibits adipogenesis in human mesenchymal stem-cells (MSC). Exp. Gerontol. 2017, 90, 71-78. [CrossRef] [PubMed]

170. Chimento, A.; Casaburi, I.; Rosano, C.; Avena, P.; De Luca, A.; Campana, C.; Martire, E.; Santolla, M.F.; Maggiolini, M.; Pezzi, V. Oleuropein and hydroxytyrosol activate GPER/GPR 30-dependent pathways leading to apoptosis of ER-negative SKBR 3 breast cancer cells. Mol. Nutr. Food Res. 2014, 58, 478-489. [CrossRef]

171. Odiatou, E.M.; Skaltsounis, A.L.; Constantinou, A.I. Identification of the factors responsible for the in vitro pro-oxidant and cytotoxic activities of the olive polyphenols oleuropein and hydroxytyrosol. Cancer Lett. 2013, 330, 113-121. [CrossRef] [PubMed]

172. Hassan, Z.K.; Daghestani, M.H. Curcumin effect on MMPs and TIMPs genes in a breast cancer cell line. Asian Pac. J. Cancer Prev. 2012, 13, 3259-3264. [CrossRef]

173. Fu, S.; Arráez-Roman, D.; Segura-Carretero, A.; Menéndez, J.A.; Menéndez-Gutiérrez, M.P.; Micol, V.; Fernández-Gutiérrez, A. Qualitative screening of phenolic compounds in olive leaf extracts by hyphenated liquid chromatography and preliminary evaluation of cytotoxic activity against human breast cancer cells. Anal. Bioanal. Chem. 2010, 397, 643-654. [CrossRef] [PubMed]

174. Goulas, V.; Exarchou, V.; Troganis, A.N.; Psomiadou, E.; Fotsis, T.; Briasoulis, E.; Gerothanassis, I.P. Phytochemicals in olive-leaf extracts and their antiproliferative activity against cancer and endothelial cells. Mol. Nutr. Food Res. 2009, 53, 600-608. [CrossRef] [PubMed]

175. Tzonou, A.; Lipworth, L.; Kalandidi, A.; Trichopoulou, A.; Gamatsi, I.; Hsieh, C.; Notara, V.; Trichopoulos, D. Dietary factors and the risk of endometrial cancer: A case-control study in Greece. Br. J. Cancer 1996, 73, 1284-1290. [CrossRef] [PubMed] 